\title{
ANALIZA DISKURSA ISTANBULSKE KONVENCIJE
}

\section{Krešimir Petković}

Fakultet političkih znanosti

Sveučilište u Zagrebu

E-mail: kpetkovic@fpzg.hr
DOI: 10.20901/an.16.06

Izvorni znanstveni rad

Prihvaćeno: prosinac 2019.

\begin{abstract}
Sažetak Autor analizira ratifikaciju Istanbulske konvencije u Hrvatskoj 2018. Nakon uvodnog prikaza temeljnih teorijskih i metodologijskih postavki, prvi dio članka analizira tekst Konvencije. Drugi dio članka analizira njezinu političku recepciju u hrvatskoj javnosti uoči, tijekom i nakon ratifikacije. Pritom se diskursi koji su se sučeljavali i surađivali uspostavljaju induktivno, na osnovi uočavanja ponavljajućih sličnosti i razlika u istupima različitih aktera u javnim medijima. Nakon analize diskurzivnih okvira rasprave, prikazuju se institucionalni i izvaninstitucionalni aspekti procesa ratifikacije koji se odigrao unutar tih okvira. Naglasak se stavlja na sklapanje diskurzivne koalicije zastupnika dominantnog diskursa o nasilju nad ženama i diskursa o obiteljskoj tradiciji koji je, uz Interpretativnu izjavu, omogućio ratifikaciju Konvencije.
\end{abstract}

Ključne riječi Istanbulska konvencija, analiza diskursa, kaznena politika, nasilje nad ženama, obiteljsko nasilje, rod, moć, ideologija

\section{Uvod}

Konvencija Vijeća Europe o sprečavanju $i$ borbi protiv nasilja nad ženama i nasilja $u$ obitelji potpisana je u Istanbulu u svibnju 2011. pod okriljem Vijeća Europe, organizacije za zaštitu ljudskih prava koja ima 47 članica, a uključuje sve članice Europske unije (EU). Nakon burne javne rasprave, Istanbulsku konvenciju potpisanu u siječnju 2013, Hrvatski je sabor ratificirao u travnju 2018. sa 130 glasova za, 30 protiv i dva suzdržana. ${ }^{1}$

\footnotetext{
Troje zastupnika nije došlo na sjednicu. Šestorica zastupnika bili su u sabornici, ali nisu glasovali, uključujući dvojicu članova vladajuće stranke (HDZ), koji su nastojali kompromisno riješiti sukob stranačke lojalnosti i deklariranoga svjetonazorskog otpora Konvenciji.
}

Stupila je na snagu u listopadu 2018, ali time nisu bili zaključeni javni prijepori o njoj, a trendovi kaznene politike u koje se uklopila nastavili su se pa i zaoštrili. U hrvatskoj je javnosti usvojeni dokument poznat pod skraćenim nazivom "Istanbulska konvencija" (u nastavku: Konvencija).

Zadaća je ovog članka analizirati diskurs Konvencije metodom kritičke analize diskursa koja u različitima strukturnim i semantičkim svojstvima pisanih i izgovorenih tekstova identificira političke ideologije, ne bježeći pritom od njihova vrednovanja (Van Dijk 2006; Wodak i Meyer 2016). Slijedeći primjere arheologijâ i genealogijâ Michela Foucaulta, autora koji je ostvario formativan utjecaj na analizu diskursa (Fairclough 
1992), s jedne, i opće postavke interpretacijske društvene znanosti, na tragu shvaćanja sociologije Maxa Webera i etnografije Clifforda Geertza, s druge strane, analiza neće pretjerano naglašavati strogo kvantitativne i formalne aspekte diskursa kao jezično posredovane političke komunikacije. Iako ću, slijedeći temeljna žanrovska pravila analize diskursa, ukazati na neka formalna obilježja diskursa, poput njegovih tropa i modalnosti, usmjerit ću se ponajprije na razumljiv sadržaj ideologija koje diskursi posreduju s obzirom na "finoću razlikovanja" (Geertz 1973: 25) njihovih pojmova $\mathrm{u}$ onome što je napisano, prikazano i izgovoreno u relevantnim slučajevima, smještajući ono tumačeno u kontekst političkog djelovanja aktera koji razumiju društvenu situaciju (Weber 1988).

Pojmovi i razlikovanja među njima dio su borbe za javni jezik u društvu. Kako tekst pišem kao politolog i kako je dokument politički kontroverzan, naglasak stavljam na odnose moći i konflikt kao interpretacijske kategorije koje zahvaćaju "velike stvarnosti" (Geertz 1973: 21) društvenog života, referirajući se na sukobe diskursa koji posreduju ideologije i s njima povezane ili od njih pozvane pripadnike različitih društvenih skupina. Ideologiju shvaćam u vrlo širokom smislu proizvodnje značenja u službi moći (Thompson 1984). Njezina je svrha očuvati ili promijeniti društvene odnose kodirajućih ih političkim diskursom (Petković 2018), a njezina je tipična tehnika propaganda u temeljnome lasvelovskom smislu kontrole mnijenja pomoću simbola (Lasswell 1938). Slijedeći Foucaulta i njegovu "analitiku moći", u analizi uvažavam neke od njegovih metodologijskih naputaka o odnosu strategija, taktika i diskursa na društvenom polju moći. To su ponajprije teze o uzajamnom uvjetovanju taktika i strategija i o taktičkoj polivalenciji dis- kursa (Foucault 1976: 131-135) koje se na području javnih politika izražavaju u literaturi o diskurzivnim koalicijama koje se formiraju oko stvaranja pojedinih javnih politika (Hajer 2003, 2006).

Prvi dio rada analizira relevantna mjesta teksta Konvencije u hrvatskom prijevodu. Drugi, središnji dio analizira diskurse koji su se formirali u hrvatskoj javnosti uoči, tijekom i nakon njezina donošenja od kraja 2017. do kraja 2019. Pritom se diskursi - četiri glavna i četiri sporedna, ali kontekstualno relevantna - koji su se sučeljavali uspostavljaju induktivno, na osnovi uočavanja sličnosti i razlika u istupima različitih aktera u javnim medijima u koje ubrajam različite televizijske kanale, novine i ponajviše brojne internetske portale raznolikih ideoloških profila u kojima su različiti subjekti tumačili tekst Konvencije, obrazlagali potrebu njezina usvajanja ili upozoravali na opasnost ako se to učini, prikazivali politička previranja u vezi s njom te spekulirali o njezinim učincima. Posljednji dio rada prikazuje sam politički proces ratifikacije u analiziranima diskurzivnim okvirima i formiranje diskurzivne koalicije koja je omogućila ratifikaciju Konvencije.

\section{Što je novo u Istanbulskoj konvenciji? Kazneni feminizam i aporije političke semantike roda}

Prije analize diskursâ koji su se formirali u kaznenopolitičkome i društvenom kontekstu te s njima povezanih političkih taktika i strategija, valja se najprije posvetiti samom tekstu. Da bismo ispravno protumačili njezine političkodiskurzivne permutacije, treba vidjeti što uopće piše u Konvenciji.

Konvenciju čine preambula i dvanaest poglavlja koja sadržavaju 81 članak te dodatak o povlasticama i imunitetima nadzornog tijela za provedbu Konvencije koje je nazvano GREVIO, što je akro- 
nim povezan sa sintagmom "Skupina za djelovanje protiv nasilja nad ženama i obiteljskog nasilja". ${ }^{2}$ Tom dokumentu od tridesetak stranica valja dodati sedamdesetak stranica službenoga "pojašanjavajućeg izvješća" s 387 numeriranih paragrafa tumačenja pojedinih članaka i njihovih stavaka koji su važni za preciznije razumijevanje i obrazloženje kaznenopolitičkih ideja dokumenta.

Dokument je, diskurzivno gledajući, hibridan. On je kombinacija diskursa feminističke sociologije, donekle i rodnih studija, i klasičnoga liberalnog pravnog diskursa reducirane univerzalnosti, kojoj se povremeno daje riječ u obliku usputnog dodatka na nekoliko mjesta gdje se ističe važnost sudjelovanja muškaraca u provedbi Konvencije i zdravorazumskog priznanja činjenica da muškarci većinom nisu nasilnici, nego da i sami mogu biti žrtve nasilja ( $\$ 27)$. Konvencija stavlja fokus na žrtvu - ženu - i opsežan katalog prava koja stječe statusom žrtve. Krovni su joj označitelji rodna osjetljivost i rodna utemeljenost nasilja te je, u tom smislu, diskurs feminističke sociologije dominantan ne samo u preambuli nego i u cijeloj Konvenciji, a posebno u njezinu tumačenju. Konvencija se sama proglašava dokumentom pozitivne diskriminacije kategoričkom odredbom da "posebne mjere koje su potrebne za sprečavanje i zaštitu žena od rodno utemeljenog nasilja" (čl. 4. st. 4) neće biti izložene prosudbi o diskriminaciji, a njezina je temeljna svrha dati "posebnu pozornost ženama žrtvama rodno utemeljenog nasilja" (čl. 2. st 2).

Umjesto sustavne rasprave o svakome pojedinom aspektu opsežnog dokumenta koji su različite strane više ili manje manipulativno prikazivale $u$ medijima $\mathrm{i}$ akademskoj javnosti, usmjerit ću se na

2 Engl. Group of Experts on Action against Violence against Women and Domestic Violence. nekoliko ključnih mjesta koja su izazvala prijepore u sučeljavanju diskursâ koje prikazujem. To su: shvaćanje nasilja; definicija roda i njezin doseg; pojam rodno osviještenih politika; propisivanje propagandnih i obrazovnih mjera; pitanje zahtjeva za rodno utemeljenim azilom; proceduralne odredbe o prijavama; uključivanje udruga civilnog društva u implementaciju Konvencije.

Konvencija definira nasilje strukturno, kao proizvod patrijarhalnoga društvenog sustava. Iako je njezin praktični kaznenopolitički smisao umnogome kažnjavanje počinitelja, odgovornost za nasilje ne pripisuje se pojedincu, nego se smatra "manifestacijom povijesno nejednakih odnosa moći između žena i muškaraca, koji su doveli do dominacije nad ženama i diskriminacije žena od strane muškaraca", te se ističe "strukturalna narav nasilja nad ženama kao rodno utemeljenog nasilja". Propisivanje kažnjavanja pojedinaca implicira autonomiju njihova djelovanja i slobodu da se ne čine kaznena djela, što je fikcija tipična za klasični diskurs prava koja je u napetosti s pripisivanjem odgovornosti za nasilje društvenim strukturama. Iz potonjega proizlazi legitimnost prevencijskog djelovanja kojim se Konvencija bavi, ali ne i kažnjavanja počinitelja koje propisuje. No taj je sukob - nekovrsna dvojna ontologija diskursa - bio manje važan za politiku njezina usvajanja pa tu temu neću razvijati. Mnogo je veću kontroverziju izazvalo definiranje roda, evocirajući naslov poznate teorijske studije Judith Butler (1990) Nevolje s rodom. Što o pitanju roda piše u tekstu?

Prema Konvenciji, '"rod' označava društveno oblikovane uloge, ponašanja, aktivnosti i osobine koje određeno društvo smatra prikladnima za žene i muškarce" (čl. 3. st. c). ${ }^{3} \mathrm{U}$ čl. 4. st. 3. ističe

U engleskom gender nije nužno suprotstavljeno sex te može označavati i spol u smislu razlike male i female, kao i njemački 
se, među ostalim, "rodni identitet" kao osobina na osnovi koje se ne smije biti diskriminacije u primjeni Konvencije. U tumačenju se navodi kako riječ rod ne zamjenjuje riječi muškarac i žena. Mjerodavan je $\$ 43$ tumačenja, naslovljen "Definicija 'roda"': "U kontekstu ove Konvencije termin rod, temeljen na dvama spolovima, muškom i ženskom, pojašnjava da postoje i društveno konstruirane uloge, ponašanja, aktivnosti i atributi koje određeno društvo smatra primjerenim za žene i muškarce". Dakle, riječ je o očekivanim ulogama muškaraca i žena - "termin 'rod' prema ovoj definiciji nije zamišljen kao zamjena za termine 'žena' i 'muškarac' koji se rabe u Konvenciji" - koje variraju društveno, a ne samo u fikcijama političkih antropologija.

No $\$ 53$ koji pojašnjava "temelje za nediskriminaciju", spominjući "rod, seksualnu orijentaciju, rodni identitet, dob, zdravstveno stanje, invaliditet, bračno stanje te status migranta ili izbjeglice ili drugi status", ističe da je "ovo otvoren popis". Specificirajući trenutačne referente te opće klauzule, taj diskurs nesumnjivo ide dalje od prijepora o raspodjeli tereta brige za kućanstvo i potomstvo parova: "Slično tome, homoseksualne, lezbijske i biseksualne žrtve obiteljskog nasilja često su isključene iz usluga potpore zbog svoje seksualne orijentacije. Određene skupine pojedinaca mogu doživjeti diskriminaciju i na temelju rodnog identiteta, što znači da rod s kojim se poistovjećuju nije u skladu sa spolom koji im je dodijeljen rođenjem. To uključuje kategorije pojedinaca kao što su transrodne i transseksualne osobe, transvestiti i ostale skupine pojedi-

Geschlecht, dok u hrvatskome i francuskom, etimološki potječući od latinskog genus, rod dvojako konotira prijenos naslijeđa (primjerice, na-rod), ali i vrstu i oblik kao apstrakcije odvojene od procesa biološke reprodukcije (primjerice, književni rodovi i vrste). naca koje ne odgovaraju onome što je društvo utvrdilo da pripada kategorijama 'muško' ili 'žensko'". Ta definicija pomiče razumijevanje rodne uloge $u$ prvim valovima feminizma $\mathrm{k}$ fluidnijem shvaćanju iz rodnih studija te primjenu Konvencije širi na manjinske seksualne i rodne identitete.

I u tome dalekosežnijem smislu koji legitimira politiku priznanja i zaštite transrodnih subjektiviteta, pojam roda odavno postoji u hrvatskom zakonodavstvu, uključujući kazneno. Pojam rod pojavio se na putu pristupanja $\mathrm{Hr}$ vatske EU, o čemu je postojao konsenzus političkih elita, te je prije aktiviranja konzervativnog dijela civilnog društva mogao zadržati podpolitičku razinu. Primjerice, Zakon o suzbijanju diskriminacije (2008) sankcionirao je diskriminaciju na osnovi "rodnog identiteta". Kazneni zakon (2011), koji je stupio na snagu 2013, uključio je članak o kažnjavanju povrede ravnopravnosti kaznom do tri godine zatvora, a među osnovama veoma široko koncipirane diskriminacije eksplicitno je navedeno i "izražavanje rodnog identiteta". 5

Što se tiče rodno osviještenih politika, one su ustvari noseći operativni pojam dokumenta koji ga premješta iz sfere liberalno shvaćenog prava na područje tradicije policijsko-kameralnih znanosti, odnosno javnih politika kao pomne regulacije društvenog života. Takav pristup ne smatra opsežniju državnu intervenciju u društveni život samo legitimnom nego i nužnom za dobrobit subjekata. Konvencija, naime, propisuje uključenje "rodne perspektive u provedbu i procjenu učinka odredaba" konvencije i propisuje "promicanje učinkovite provedbe politika ravnopravnosti žena i muškaraca te osnaživanje žena" (čl. 6). U tom smislu, rod ponajviše ostaje

\footnotetext{
V. NN 85/2008, čl. 1. st. 1.

V. čl. 125. NN 125/2011. i izmjene u: NN $144 / 2012$
} 
kod društvenih uloga muškaraca i žena kao subjekata Konvencije - dokumenta distributivne pravednosti koji propisuje tko što zaslužuje i koja je diskriminacija opravdana, a koja je nedopustiva. Štoviše, on u tim okvirima ima ambiciju fukoovski shvaćene guvernmentalnosti kao vladanja vladanjima, koja se bori protiv "rodnih stereotipa te običaja i tradicija koji su rodno polarizirani", pa pojedinim svojim odredbama propisuje cilj da "utječe na srca i umove pojedinaca koji svojim ponašanjem pridonose održavanju oblika nasilja koje pokriva opseg ove Konvencije" (\$ 85).

To vrijedi i za obrazovanje, ako ostajemo kod teksta Konvencije i njezina službenog tumačenja. Vjerojatno je najviše prijepora u javnosti izazvalo treće poglavlje o prevenciji, napose članci 12-14, gdje dokument posebno jasno izlazi iz okvira prava u domenu javnih politika. Čl. 12, koji stipulira opće obveze stranaka, govori o poduzimanju "potrebnih mjera" za "promicanje promjena u društvenima i kulturnim obrascima ponašanja žena i muškaraca s ciljem iskorjenjivanja predrasuda, običaja, tradicija i svih drugih postupanja u praksi koja se temelje na ideji manje vrijednosti žena ili na stereotipnim ulogama žena i muškaraca." Čl. 13, eksplicitno propagandnog naslova "Podizanje razine svijesti", propisuje "promicati ili provoditi, redovno i na svim razinama, kampanje i programe podizanja razine svijesti", i to "u suradnji s nacionalnim institucijama za ljudska prava i tijelima za ravnopravnost, organizacijama civilnog društva i nevladinim organizacijama, osobito ženskim organizacijama", uz diskrecijsku klauzulu "kad je to primjereno". Čl. 14, posebno usmjeren na "Obrazovanje", propisao je pak, uz istu klauzulu, "potrebne korake kako bi nastavne materijale o pitanjima kao što su ravnopravnost žena i muškaraca, nestereotipne rodne uloge, uzajamno poštovanje, nenasilno rješavanje sukoba u osobnim odnosima, rodno utemeljeno nasilje nad ženama i pravo na osobni integritet, prilagođeno razvojnim sposobnostima učenika, uključile u redovni nastavni plan i program i na svim razinama obrazovanja". Tome valja dodati odredbe koje zabranjuju multikulturna opravdanja koja bi oblike nasilja legitimirala kulturnim obrascem (čl. 42). Pojašnjenje u $\$ 94$. govori pak o "ravnopravnosti spolova" i promicanju nenasilja, dakle ne govori o transrodnom kurikulu, te ističe slobodu medija i tiska.

S druge strane, pitanja migracija i nedopuštene diskriminacije proširuju pojam roda, makar kao opciju za stranke Konvencije. Uz rodno osjetljivo tumačenje straha od proganjanja i rodno osjetljive postupke prihvata, rodno osjetljive intervjue itd., koji propisuju široku pozitivnu diskriminaciju imigrantica, čl. 60. "Zahtjevi za azil utemeljeni na rodu" propisuje da se "rodno utemeljeno nasilje nad ženama" priznaje kao oblik proganjanja te postaje osnovom za stjecanje prava azila. St. 2. propisuje da se "rodno osjetljivo tumačenje prida svakoj od osnova iz Konvencije", a st. 3. "zakonodavne ili druge mjere kako bi razvile rodno osjetljive postupke prihvata i usluge za potporu tražiteljima azila, kao i rodno osjetljive smjernice i postupke za azil, uključujući i utvrđivanje statusa izbjeglice te zahtjev za međunarodnu zaštitu". Stavak se odnosi na žene koje su žrtve "rodno utemeljenog nasilja", ali $\$ 87$. kao subjekte posebno izložene povredi prava ističe "nezabilježene migrante i izbjeglice, homoseksualne muškarce i žene, biseksualne i transrodne osobe". \$ 313 eksplicitan je u shvaćanju subjektivnosti roda, ali u pogledu modalnosti nije kategoričan nego kondicionalan, prepuštajući širenje područja roda volji stranaka: "Nadalje, pri osiguravanju rodno osjetljivog tumačenja svake osnove iz Konvencije, Stranke, ako žele, mogu 
proširiti ovo tumačenje na pojedince koji su homoseksualni, lezbijke, biseksualni ili transseksualni, koji se također mogu susresti s posebnim vrstama proganjanja i nasilja povezanih s rodom".

Što se tiče procedure tretiranja nasilja u obitelji, pojavljuje se detalj koji je iznimno bitan za vlasništvo nad sukobom na području nasilja nad ženama i u obitelji te onemogućuje subjektima slobodu upravljanja vlastitim sukobima i reprivatizaciju nasilja, kako ga shvaća Konvencija. Naime, Konvencija se primjenjuje "neovisno o naravi odnosa između žrtve i počinitelja" (čl. 43) i donosi kategorički proceduralni pomak politike prijave iz ex parte u ex officio pokretanje postupka, pa stranke moraju osigurati da "istrage ili progon kaznenih djela... ne smiju ovisiti u potpunosti o prijavi ili pritužbi koju je podnijela žrtva, ako je kazneno djelo počinjeno u cijelosti ili djelomično na njihovom državnom području, te da se postupak može nastaviti čak i ako žrtva povuče svoju izjavu ili pritužbu" (čl. 55. st. 1). To u hrvatskom kontekstu znači neku vrstu pozitivne diskriminacije na području kaznenog prava obitelji, jer se tjelesne ozljede, ako nisu počinjene prema bliskoj osobi ili prema službenoj osobi u obavljanju dužnosti, progone po privatnoj tužbi, a ne obvezom postupanja javnog tužiteljstva u javnom interesu. Konvencija kategorički zabranjuje i "obvezne alternativne postupke rješavanja sporova... uključujući medijaciju i mirenje" (čl. 48), čime se kazneni proces u obitelji učvršćuje kao jus cogens države, a ne nešto što stranke mogu alternativno ugovoriti. ${ }^{6}$

Kada je riječ o proceduralnim pomacima ka zaštiti onih koji steknu status žrtve u procesu, valja ukazati na još jednu kaznenopolitički relevantnu odredbu

6 Usp. \$ 187. uz. čl. 35: "Ovaj članak kriminalizira svaki čin fizičkog nasilja nad drugom osobom bez obzira na kontekst u kojem se dogodi". koja se bori protiv "rodnih stereotipa" i sugerira uvođenje anglosaksonskih rape shield-odredbi u kazneni proces koje sužavaju dopustivost određenih dokaza, propisujući "da će, u svim građanskim ili kaznenim postupcima, dokazi vezani uz seksualnu povijest i ponašanje žrtve biti dopušteni samo kad je to važno i nužno" (čl. 54). No $\$ 278$. ipak specificira da se a priori "ne odbacuje prihvatljivost takvih dokaza". Iako se od stranaka Konvencije "zahtijeva da poduzmu mjere nužne za promicanje promjena u mentalitetu i stavovima" ( $\$ 85$ ), ipak se ne zatvaraju vrata pravičnom procesu u kojemu optužba u bitnom zadržava status tvrdnje stranke u akuzatornom postupku koja se može potkrijepiti dokazima ili opovrgnuti u sudnici.?

Taj međunarodni dokument uključuje udruge civilnog društva kao sastavni dio implementacije: "Stranke će prepoznati, poticati i podržavati, na svim razinama, rad odgovarajućih nevladinih organizacija i organizacija civilnog društva aktivnih u borbi protiv nasilja nad ženama te uspostaviti učinkovitu suradnju s tim organizacijama" (čl. 9), što je novum na području kaznene politike koja se tradicionalno, makar u krajnjoj liniji, smatrala državnim poslom. Čl. 66. st. 4.a ističe da članovi GREVIO-a "moraju biti izabrani u transparentnom postupku među osobama izraženih moralnih osobina, poznatim po visokoj razini stručnosti u području ljudskih prava, ravnopravnosti spolova (eng. gender equality), nasilja nad ženama i nasilja u obitelji ili pomoći i zaštite žrtava ili koje su pokazale profesionalno iskustvo u područjima koje obuhvaća ova Konvencija". Ekipiranje tog tijela, očekivano, čvrsto ostaje unutar partikularnoga diskurzivnog prosto-

Usp. $\$ 262$. koji, ipak, upućuje na određenu razinu kulturnog treniranja rodne osjetljivosti na području prava: "Kada suci prihvate dokaze o prethodnoj seksualnoj povijesti, potrebno ih je predstaviti tako da ne dovode do sekundarne viktimizacije". 
ra Konvencije, što je otvorilo prostor za razvijanje bogate subverzivne metaforike diskursa koji se protive Konvenciji.

U konačnici, može se zaključiti da je diskurs Konvencije hibridan i mjestimice ambivalentan. To umnogome nije jezik kaznenog prava nego javnih politika. Njegova je ambivalentnost pridonijela kontroverzijama. Ponekad osebujni diskursi dobili su prostor za politiziranje interpretacijski otvorene materije, koju ona sama priziva kao intertekstualni dokument satkan od različitih diskursa među kojima postoje napetosti. Konvencija je ponajviše dokument feminističke javne politike koji u vezi s nasiljem nad ženama i obiteljskim nasiljem širi područje nediskriminacije, marginalno ga povezujući sa zaštitom seksualnih i rodnih identitetskih izričaja koji odstupaju od heteroseksualne tradicije koja se na Zapadu, ali i globalno, u posljednje vrijeme propituje kao opresivna u sklopu zamaha društvenih pokreta i proširene politike priznanja. Dokument se u bitnom doista odnosi na uloge muškaraca i žena te ostaje u tim okvirima na području obrazovanja, ali širi pojam roda, posebno u vezi s politikama azila, na različite rodne identitete i sugerira njihovu zaštitu.

\section{Sukob diskursâ u tumačenju Istanbulske konvencije}

U ovome dijelu rada analiziram političke diskurse koji su se pojavili u procesu ratifikacije Konvencije. Iz njih izdvajam taktičke elemente iz kojih se formirala strategija usvajanja dokumenta u odnosu institucionalne i izvaninstitucionalne politike s obzirom na unutarstranačke i međustranačke odnose i aktere civilnog društva. Ukupno je analizirano 360 tekstova s internetskih portala i iz dnevnih novina te 20 televizijskih emisija. Najviše ih je bio od listopada 2017. do travnja 2018, ali sam u analizu uključio i artikulacije nastale do listopada 2019, ako su bile relevantne za problematiku, jer se Konvencija učestalo politički evocirala $\mathrm{u}$ javnom prostoru i nakon ratifikacije.

Premda nisu obrađeni svi medijski izvori i tekstovi, uzorak daje valjan presjek relevantnih artikulacija koje su oblikovale javnu recepciju Konvencije i utjecale na politički ishod. Neki dokumenti nudili su gotovo singularne artikulacije vrijednosnih pozicija - najčešće portalske i novinske kolumne - dok je većina drugih sadržavala sučeljavanja pozicija i političke analize na različitim razinama intertekstualnosti, što je jedan od razloga zbog kojih se ne mogu pobrojati dokumenti "za" i "protiv", pa čak ni oni koji pripadaju jednome od analitički uspostavljenih diskursa. ${ }^{8}$ Nastojao sam uključiti širok ideološki spektar izvora s portala i iz novina te uzeti u obzir tekstove i komentare ispod njih. $\mathrm{U}$ obzir sam uzeo tekstove s portala Libela (Li), H-alter (H-a), Ideje (Id), Telegram (Tg), Indeks (In), Novi list (NL), T-portal (Tp), Jutarnji (JL), 100posto (100\%), Slobodna Dalmacija (SD), Večernji (VL), 24sata (24s), Dnevnik (Dn), Direktno (Dr), Maxportal (Mp), Dnevno (Dn), 7dnevno (7D), i Narod (Na). Prema gruboj prostornoj dihotomiji koja zakriva više ideoloških dimenzija, prvi se smatraju lijevima, slijede oni s lijevoga i desnog centra te desni. Kolumnisti i tekstovi u Večernjem i Direktnom pojavljuju se s obzirom na pitanje ratifikacije u ideološkom međuprostoru i "za" i "protiv" Konvencije, dakle mimo njihove uvriježene ideološke percepcije. Od tiskanih novina uzeo sam $\mathrm{u}$ obzir Jutarnji (JLt) i Večernji list (VLt), prigodno i vrlo ograničeno, jer su sadržaji uglavnom bili dostupni na portalima, te

$\mathrm{U}$ istom se tekstu pojavljuju sukobljene izjave političara, nekad se pojedini isječak teksta ironizira, ili se temeljna diskurzivna struja teksta od njega ograđuje, ili ga pak izravno osuđuje: u igri je složena komunikacija koja bitno otežava pa i onemogućuje urednu kategorizaciju. 
televizijske emisije s Al-Jazeere, HRT-a i Z1, dakle s regionalne, nacionalne i lokalne televizije, koje također prezentiraju širinu ideološkog spektra izborom gostiju, moderiranjem i uokvirivanjem rasprave o Konvenciji. ${ }^{9}$ Radi ekonomičnosti, u bilješkama uz citate navodim naslov teksta, kraticu izvora u zagradama iz prethodnih rečenica i datum javne objave ili emitiranja. U navode ne interveniram pravopisno ili gramatički nego ih doslovce prenosim, što vrijedi i za često živopisne komentare koji su dio političke komunikacije i ne treba ih eufemizirati.

Induktivno sam ustanovio četiri glavna diskursa koja su dominirala u javnosti i nekoliko marginalnih po političkoj logici diskurzivnog koaliranja i određivanja koordinata rasprave. Klasifikacija ne govori o tome jesu li diskursi istiniti ili lažni, dobri ili loši, nego o njihovoj zastupljenosti u medijima i političkoj relevantnosti. Logika njihove pozicije nije nužno logika stvari te - premda ću uz jednoga donekle normativno pristati, jer se to u žanru kritičke analize diskursa očekuje - to nije srž analize koja prikazuje jedan politički trenutak u isječku vremena.

U prikazu dajem izbor relevantnih navoda iz tekstova i njihovu analizu, prezentiram središnju temu ili preokupaciju diskursa i njezino vrednovanje, političkog subjekta kojeg interpelira te skiciram glavnu liniju ideološke argumentacije. Induktivna konstrukcija diskursa kreativan je interpretacijski proces koji se temelji na razumijevanju distinkcija unutar smislenih cjelina tekstova, koje se zatim nastoje potvrditi analitičkom razradom. Sam proces, makar u ovom radu, nema smisla formalizirati.

9 Čitatelj će uočiti izostanak televizijskih postaja RTL i NOVA, portala Bitno i drugih, no negdje sam se morao zaustaviti. Čak je i Gloria povremeno bila relevantna za temu.
Ako on jest nešto što pripada crnoj kutiji "znanstvenog otkrića" i konstrukcije hipoteza, vjerujem da bi i drugi istraživači došli do sličnih ocjena, premda ih možda ne bi znanstveno nazvali i analitički zahvatili potpuno jednako.

Četiri glavna diskursa su: (1) nasilje nad ženama, ${ }^{10}$ (2) vladavina žena, (3) politika priznanja i (4) obiteljska tradicija. Prvi je diskurs feministički i upozorava na nasilje nad ženama koje treba prevenirati obrazovanjem i građanskim odgojem te suzbiti oštrim i ažurnim kažnjavanjem s nultom stopom tolerancije. Drugi je patrijarhalan i upozorava na opasnosti matrijarhata: žene polako preuzimaju kontrolu javnog jezika i aparat represije koji muškarce čini nekom vrstom suvremenoga političkog roblja. Treći se zauzima za javnu afirmaciju i zaštitu različitih seksualnih identiteta i rodnih izričaja, bez obzira na spol, kojima se moraju prilagoditi javni jezik i kažnjavanje. Četvrti se protivi rodnoj ideologiji kao načinu uništavanja tradicije obiteljskih odnosa i reprodukcije društva te Konvenciju tumači kao dio neumoljive transnacionalne agende koji razara tradicionalno tkivo društva. Pojavilo se još izdvojivih diskurzivnih pozicija - (5) identitarno domoljublje, (6) radikalni ekonomizam, (7) religijska eshatologija i (8) republikanizam kažnjavanja - koje su bile kontekstualno relevantne i u pojedinim se istupima više ili manje isprepleću s glavnim diskursima.

10 U jeziku aktivistica sve je učestalije doslovno prevođenje sintagme violence against women kao "nasilje protiv žena", s intencijom dodatnoga horizontalnog politiziranja tog oblika nasilja, ali u javnom diskursu u Hrvatskoj još se češće govori o "nasilju nad ženama", a ponekad i o "nasilju prema ženama". Nasilje nad ženama pojavljuje se redovito u istupima subjekata koji ga smatraju gorućim društvenim problemom pa sam ga zadržao kao krovnog označitelja dominantnog diskursa $\mathrm{u}$ analiziranom slučaju. 
Temeljni je paradoks analize sljedeći: usvajanje Konvencije nije odredio frontalan sukob politike priznanja i obiteljske tradicije u kojemu bi potonja bila poražena, ili patrijarhata i matrijarhata, nego diskurzivna koalicija feminističkoga i obiteljaškog diskursa o nasilju nad ženama, dok se njihovo nesuglasje o politici priznanja, odnosno o rodnoj ideologiji riješilo taktičkim kompromisom kroz Interpretativnu izjavu koja je dodana Konvenciji. U tom ću sklopu podrobnije prikazati četiri dominantna diskursa, zatim one manje važne ili marginalne, da bih kratkom analizom medijatiziranoga političkog procesa, usmjeravajući se na različite diskurzivne momente i političke događaje, u zaključnom dijelu rada ukazao na njihovo sučeljavanje i suradnju koji su oblikovali političke ishode koje je izvršna vlast sakralno prezentirala kao svoj autorizirani izbor javne politike (Colebatch 2004).

\section{Nasilje nad ženama}

Diskurs o nasilju nad ženama uglavnom ostavlja postrance pitanja raznolikosti rodnog identiteta i njihova priznanja. On govori o nasilju muškaraca nad ženama koje se događa u odnosima moći u privatnoj sferi, a povezano je sa stereotipima i očekivanjima u tim odnosima koji se kulturno reproduciraju. U promatranom uzorku bio je najviše zastupljen u srednjostrujaškim medijima, ponajviše u Jutarnjem i Večernjem listu i s njima povezanima portalima, kao i na javnoj televiziji. Ključno je za taj diskurs to što se krovna sintagma rodno uvjetovanog nasilja nad ženama, uz zaoštreno zgražanje i kolokvijalnu samorazumljivost, oštro razdvaja od rodne ideologije:

"Potpuna je izmišljotina da Istanbulska konvencija donosi 'rodnu ideologiju' koje nema drugdje i to mogu navoditi samo oni koji nemaju pojma što je u CEDAW i što je to nasilje nad ženama - to je uvijek rodno uvjetovano nasilje koje se odnosi na žene zato što su žene ili ono koje prekomjerno pogađa žene, a može imati različite oblike od psihičkog, fizičkog, seksualnog do ekonomskog. Kad ne bi bilo te definicije, onda bi svako nasilje bilo nasilje nad ženama. Rodno uvjetovano nasilje nad ženama oblik je diskriminacije žena i predstavlja kršenje ljudskih prava. Ili još jednostavnije: kod nas je termin 'Gender Equality' preveden kao 'ravnopravnost spolova', a zapravo je engleski termin 'Gender' - 'rod', a ne spol". ${ }^{11}$

U tim se diskurzivnim operacijama rod nije nužno tretirao s posebnom pažnjom. ${ }^{12}$ Usvajanje Konvencije nastojalo se depolitizirati ("Ponavljam da je Istanbulska konvencija civilizacijsko pitanje, a ne političko - kazao je Sponza") i povezati s napretkom ("Ovo je trenutak u kojem odlučujemo hoćemo li biti napredna ili zaostala zemlja - poručila je Mrak Taritaš"). ${ }^{13}$ Problematika koja je uzbuđivala četvrti diskurs zaštite obiteljske tradicije reducirana je na "lingvističko pitanje", dok se važnost borbe protiv nasilja nad ženama potkrepljivala dramatičnim prikazima povijesnih i suvremenih slučajeva patnje zbog nasi-

11 "Hrvatska može spriječiti ubijanje žena, ali vlade su mi se žalile da im je to preskupo!", JL, 26. 2. 2017.

12 "Ako koja ima nešto nakaradno što se nama ne sviđa, to nije nešto što Istanbulska konvencija podržava." ("Branka Žigante Živković: 'Rodno utemeljeno nasilje vidi se u svakom sudskom spisu'", VL, 12. 3. 2018).

13 "Ustavna stručnjakinja: 'Neće biti neočekivano ako Hrvatska zbog ove izjave bude snosila političke posljedice'", JL, 22. 3. 2018. 
lja, ${ }^{14}$ statistike nasilja, ${ }^{15} \mathrm{~s}$ više ili manje preciznosti i manipulativnih elemenata prezentacije. Metonimijskim frazama ocrtavani su modaliteti nasilja nad ženama, povezivani s općom nazadnošću i obvezom kažnjavanja. ${ }^{16}$ Odbacivana je kritika prema kojoj Konvencija zadire u tradiciju i suprotstavljana je kolokvijalnijim inačicama sintagme o nasilju nad ženama: "Drugim riječima, ne traži se podčinjavanje vjere, kulture, običaja i tradicije Konvenciji nego se traži da to ne može biti opravdanje za, primjerice, premlaćivanje žena. I doista nije jasno što je u tome sporno, osim ako netko nije zagovornik takvih praksi". ${ }^{17}$ Kritika Konvencije smještala se u registar ideološki motivirane moralne panike, a sama

14 "Mara, kao ni bilo koja druga žrtva obiteljskog nasilja, nije samo žrtva muža nasilnika, nego i sredine - naime svih koji ga štite svojom šutnjom i prešućivanjem... Njen slučaj je potvrda da kao građani, stranke i društvo u cjelini obiteljsko nasilje ne uzimamo ozbiljno, da se i dalje ponašamo kao da je to privatni a ne društveni problem. Zato je prihvaćanje Istanbulske konvencije naprosto nužda". ("Slavenka Drakulić, "Kako će supruga požeškog župana dalje? Novca nema, a u Požegi ne može naći odvjetnika koji bi je zastupao pro bono", JL, 22. 10. 2017).

15 Usp. "HRVATSKA SRAMOTA. Lani je ubijeno 20 žena, njih 18 ubile su bliske osobe ili partneri", NL, 21. 11. 2017. "Nadam se da nitko ne spori da je to glavno nasilje statistike su upravo zanemarive u odnosu na nasilje žena prema muškarcima". ("Sanja Barić: Neznanje i laži oko Istanbulske konvencije koriste se radi očuvanja položaja žene kao 'drugotne'", NL, 8. 1. 2018).

16 "'Šaka u glavu i metak u čelo nije pitanje rodne ideologije, nego primitivizma i kaznenog djela koje se mora učinkovito i brzo sankcionirati', poručio je Klisović, dodajući da Istanbulska konvencija za to daje čvrsti okvir". ("SDP: Istanbulska konvencija je 'civilizacijski iskorak', 'klerikalni krugovi' vrše pritisak na premijera", Na, 24. 10. 2017).

17 "Protivnici Istanbulske konvencije manipuliraju njenim sadržajem. Donosimo konkretne primjere za to", NL, 28. 11. 2017. je sintagma "rodna ideologija" odbacivana uz zgražanje:

"Nemam problema kada se ljudi bore za ono što vjeruju, no smatram nakaradnim kada za to koriste laži, pogotovo kada su ovako odvratne... Dječaci će ostati dječaci, a djevojčice će ostati djevojčice. Spol se ne bira, on je biološki zadan i nitko nikoga u školi ili bilo gdje drugdje neće učiti da mora odabrati hoće li biti muško ili žensko. To nema veze sa zdravim razumom... Tzv. rodna ideologija izmišljena je kategorija ideoloških ratnika koji se opet bore protiv imaginarnih neprijatelja... Točno je da se spominju i transrodne osobe. Kolokvijalno rečeno, to su osobe koje osjećaju da su se rodile u krivom tijelu. Radi se o izvanredno malom postotku ljudi i oni ni na koji ne ugrožavaju nas ostale... Dakle, opustite se. Rodna ideologija ne postoji... Doista je toliko jednostavno!"18

$\mathrm{U}$ javnom prostoru isticala se znanstvenost pristupa nasilju nad ženama, posebno u perspektivi društvenih znanosti ("na temelju ozbiljne znanstvene rasprave", "stavom uglednog sociologa", "kojekakve neznanstvene politikantske nakane"19), a napose sociologije na koju se pozvao i autor prethodnoga izdvojenog navoda. No ključno je bilo reducirati značenje Konvencije na nasilje nad ženama i isključiti druge moguće načine uokvirivanja njezina sadržaja: "Istanbulska konvencija je pisana jedno-

18 "BRUNO ŠIMLEŠA: Nemam problema kada se ljudi bore za ono što vjeruju, no smatram nakaradnim kada za to koriste laži, pogotovo kada su ovako odvratne", JL, 1. 12. 2017. Usp. i "U crkvi u Našicama dijelili letke protiv Istanbulske konvencije, pogledajte kakvim gadostima truju građane", In, 3. 1. 2018.

19 "Biljana Kašić: Nema nikakvog političkog niti znanstvenog razloga da Hrvatska ne ratificira Istanbulsku konvenciju", NL, 8. 1. 2018. 
stavnim jezikom i isključivo je fokusirana na rodno uvjetovano nasilje prema ženama samo zbog toga što su žene". ${ }^{20}$ Taktika sužavanja značenja Konvencije i zadržavanja fokusa isključivo na nasilju nad ženama ponekad bi bila zamijenjena borbenijim upozoravanjem na patrijarhat, antagoniziranjem petog diskursa o nacionalnom identitetu s kojim je povezivana povijesna dominacija nad ženama. Pritom bi se sintagma rodne ideologije, noseća za četvrti diskurs, primjenjivala natrag na njegovu vlastitu poziciju: "'Povijest tzv. 'rodne ideologije' ustvari je povijest dominacije patrijarhalne države i Katoličke crkve, pri čemu su, kroz povijest, žene 'drugotne', zbog čega su, primjerice, spaljivane kao vještice, morale su nositi pojas nevinosti, silovane su i sakaćene u ime vjere i nacije i države kao fetiša, prisiljavalo ih se da rađaju protiv svoje volje za naciju, vjeru i državu, umirale su zbog nestručnih pobačaja i bile su dvostruko eksploatirane, na poslu i kod kuće', podsjeća dr. Lepušić". ${ }^{21}$

Da je diskurs o rodnoj ideologiji i sam vrsta oprečne rodne ideologije pokušao je pokazati Žarko Puhovski, pišući o "tisućljetnoj praksi podruštvljavanja muško-ženske/žensko-muške seksualnosti", istaknuvši kako je upravo u kršćanskoj tradiciji "rod - u svakome slučaju društveno interpretirana spolnost - $\mathrm{u}$ Knjizi... nedvosmisleno odvojen od pütene (danas bi se reklo: biologijske) tjelesnosti". ${ }^{22}$ Slaven Letica zasjeo je pak na dva

20 "Pravobraniteljica Ljubičić koja zagovara rodnu ideologiju - manipulira činjenicama o Istanbulskoj konvenciji", Na, 25. 11. 2017.

21 "Svaka treća žena u Hrvatskoj žrtva je nasilja/'Pojačava i nasilje nad seksualnim i reproduktivnim pravima - moramo što prije ratificirati Istanbulsku konvenciju!'", $100 \%, 25.11 .2017$

22 Žarko Puhovski, "Bilo kuda, rod je svuda... od Biblije na dalje", Id, 16. 3. 2018. Polemika koja je uslijedila između Puhovskog i Matka Marušića uvelike se bavila aporijom diskurzivna stolca baveći se tom temom. Podržao je protest protiv "rodne anarhije i kaosa koji stvaraju 'rodni radikali' koji bi željeli ozakoniti pravo svakog pojedinca na spolno i rodno samoodređenje koje se danas već penje na 50-tak mogućnosti", no odbacio shvaćanje da je "'rodna ideologija skrivena u nekim paragrafima IK kao metaforičko kukavičje jaje; da se to zlo mimikrijski skriva iza pokliča o nužnosti zaštite žena i ranjivih članova obitelji od nasilja". Letica nije pristao na slobodoumno širenje područja roda koje je naznačio diskurs Puhovskoga, ali ga je odbio povezati s

siluje li bik kravu. Marušić je tvrdio da ne siluje ("bik je prema kravi nježan! Naravno, bikovski.") te svoju poziciju protumačio kao neku vrstu prirodnopravne teorije ("Prirodni zakon kaže da je prirodno da su oba spola biološki zadani i različiti"). ("Prof. Marušić odgovorio Puhovskom na navode o rodnoj ideologiji: Evo u čemu se ne slažu!" Na, 23. 3. 2018). Nastavljajući svoju argumentaciju o društvenom kultiviranju spolnosti, Puhovski je na to ironično replicirao da ne može "konkurirati dubini uvida što ih M.M. ima u psihu bikova i krava", dodao da je njegov "argument da je ta 'nježnost' možda podobna za bikove, ali nije za (današnje) ljude - koji takvu praksu milenijima sankcioniraju kao silovanje" te nazvao Marušića "samozvanim katoličkim biologom" ("Puhovski: Marušić se sprda i s vjerom, zbog nedomišljenosti, naravno", Id, 20. 3. 2018). Usp. i: "Apostol Pavao sigurno bi bio iznenađen na koji je način u Istanbulskoj konvenciji aktualizirana njegova slobodarska teza rodne teorije da 'nema više ni muškoga ni ženskog'. Iako je prvotna intencija Istanbulske konvencije bila spriječiti nasilje nad ženama kao i nasilje u obitelji, ona je nažalost u hrvatskoj javnosti percipirana kao rodna ideologija koja će stvarati novi ideal anemičnog muškarca, zalizanog maminog sineka, bruxelleskog japijevca", čime autor oštricu usmjerava na premijera Plenkovića. (Jure Zovko, "Istanbulska konvencija - HDZ-ova omča oko vrata!", 7d, 1. 4. 2018.) te tekst Slavenke Drakulić "Rodnu ideologiju propovijeda i Crkva, a da mnogi vjernici ni ne znaju da se radi upravo o tome, dovoljno je vidjeti što je još 1955. pisao Stepinac" (JL, 1. 4. 2018). 
Konvencijom tvrdeći da "zlo i zli ne čuče i ne skrivaju se među recima Istanbulske konvencije, ali vrebaju u sklopu pokreta koji želi ozakoniti spolnu i rodnu anarhiju". Svoju je poziciju nazvao kršćanskim realizmom i povezao je sa snažnom pastirskom figurom kardinala Franje Kuharića. ${ }^{23}$ Nasuprot Puhovskom koji se uvijeno približio trećem diskursu politike priznanja, Letica je na razini zagovora ostao čvrsto unutar prvog diskursa kojemu je nasilje nad ženama master signifier Konvencije, istovremeno se smjestivši unutar diskursa obiteljske tradicije o rodnoj ideologiji.

Dominantna taktika unutar diskursa o nasilju nad ženama ipak nije bilo širiti pojam rodne ideologije na suprotnu poziciju koja ne razumije samu sebe, nego zgroženo odbaciti sam označitelj rodne ideologije uz pokoju borbenu metaforu ${ }^{24}$ ili je pak implicitno prihvatiti i otpisati kao nešto nevažno, što će u političkom procesu diskurzivnog koaliranja omogućiti usvajanje Konvencije uz ogradu: "Po mom sudu, predložena interpretativna izjava Vlade RH ne mijenja značenje Konvencije, već pojašnjava njezinu točnu interpretaciju, jer Konvencija doista ne zahtijeva uvođenje rodne ideologije u hrvatski pravni i obrazovni sustav, kao ni obvezu promjene ustavne definicije braka". ${ }^{25}$

${ }^{23}$ Letica, "Kuharićev poučak o Istanbulskoj konvenciji: kardinal bi je podržao i molio da zlo ne prevlada", VL, 19. 3. 2018.

24 "Rodna ideologija izmišljeno je čudovište kojim konzervativci plaše javnost", VL, 19. 3. 2018.

25 Dubravka Šimonović, "Interpretativna izjava je opravdana i otklonit će sumnje oko uvođenja tzv. rodne ideologije", JLt, 12. 4. 2018. Usp. i: "Svaki dokument koji želi spriječiti nasilje ću podržati, a 'rodni dio' se može 'ispustiti', odgovorila je upitana za stav o ratifikaciji Istanbulske konvencije. Konvencija ima 'pretežito' dobre stvari, štiti i prava djece, kaže Pirnat Dragičević". ("Tko su dvije predložene kandidatkinje za novu pravobraniteljicu za djecu?", JL, 18. 10. 2017).

\section{Vladavina žena}

Diskurs koji ističe vladavinu žena i obespravljivanje muškaraca novim stereotipima i sredstvima kaznene politike odbija etiketu patrijarhalnosti, ne nužno kao nešto što ne bi zagovarao da može, nego prije kao podpolitičko žaljenje za dobrima starim vremenima. ${ }^{26}$ Njegov je problem u odnosu prema prirodnim danostima fiktivna politička vladavina žena koja se služi sredstvima afirmativnog djelovanja, pozitivnom diskriminacijom i selektivnim kažnjavanjem kojima se utvrđuje dominacija u privatnoj sferi. ${ }^{27} \mathrm{~S}$ time povezuje naracije o

${ }^{26}$ Usp. živopisan komentar Nade Jurinčić, kombiniran s diskursom protiv raskola $\mathrm{i}$ metonimijskom kvalifikacijom premijera kojega je u prolazu uštipnuo predsjednik Europske komisije: "Ma o čemu ti to? O kakvom patrijarhatu pričaš i to ovih dana kad od ženturača ne možemo disati ni mi žene, ni muškarci. Da ti nije Štipoguz možda -patrijarhat? Izađi u grad nedjeljom dopodne - puni kafići žena - pitam se kuha li ijedna ručak ili će 'muški teroristi' donit gotovo i 2x skuplje?! Mlađe se mlate po ulici i nose tenisice 43. Polako postaju ženturače a ne žene. Cilo društvo je feminizirano a vi vičete 'držte lopova'! MI žene rađamo i mušku i žensku dicu i odgajamo ih. I NE DAM NIKOME NI NA MUŠKIĆE NI NA ŽENSKICE! Jesi čula! Da si malo više žena od 'zone ugroženosti' onda bi shvatila da Ikača služi za RAZDOR između žena i muškaraca a samo su jedna žena i jedan muškarac JAMSTVO OBITELJI, NARODU I DRŽAVI. Zato ne palamudi jer od palamudanki mi pada mrak na oči. Il puštaj brkove il budi ŽENA a ne ŽENTURAČA". ("O jednom članku Istanbulske nitko ne priča, a trebaju ga pročitati svi muškarci i oni koji se tako osjećaju", Dr, 23. 3. 2018).

27 "U moru optužaba o potlačenosti žena, svi izbjegavaju reći da o budućnosti ove zemlje, budućnosti i životima naše djece apsolutno odlučuju žene. U $99 \%$ sporova na sudu, obrada po centrima soc. skrbi i centara za pomoć parovima u brakorazvodu, sve je u rukama žena. One imaju apsolutnu moć i o svemu odlučuju. Rezultati su porazni". Anoniman komentar uz: "Popović: Pitajte 
dekadenciji i propasti društva koje pristane na progon muškaraca koji mogu održavati autoritet u zajednici i braniti društvo od izvanjskih intruzija, dok javne politike države stalno derogiraju njihov položaj u društvu, napose u obitelji. Taj se diskurs smjestio uglavnom $u$ anonimnim komentarima kao neka vrsta redovito prisutnoga subverzivnog kontradiskursa. Dok su modaliteti izričaja prvog diskursa bili kategoričko zahtijevanje onoga civiliziranog, neka vrsta jasne naredbe ili pak najava neizbježnog napretka, diskurs o vladavini žena odao se zlogukom proricanju propadanja i dramatičnim političkim metaforama: "RTL je pritom na splitskoj rivi zabilježio neobičnu izjavu jednog neimenovanog svećenika, koji je komentirao svoje protivljenje konvenciji na ovakav način: 'Ova konvencija ide za tim da uništi ono što je najbitnije - obitelj, djecu, roditelje. Vodit će nas žene koje će biti iznad Sabora i one će zapovijedati što će se raditi. One će biti iznad sudstva, iznad države, iznad svega. Postat ćemo robovi'". ${ }^{28}$

Budući da se pojavio u komentarima, taj je diskurs operirao u kolokvijalnijemu i vulgarnijem registru, a neprijatelja je jasno našao u feminizmu kao nekoj vrsti ideologije koja katalizira izopačenost ženskog spola, a kojoj se dodaju različiti kvalifikatori koji sugeriraju isključivost i opasnost: "Istanbulska konvencija ničem drugom ne služi no osudi muškog spola. Nijedan muškarac ne bi smio dići ruku za taj pogani papir koji su sastavile ekstremne feministice". ${ }^{29}$ Ontologija koju je implicitno koristio otprilike je kombinacija biblijske žene koja seksualno salijeće muškarca i, bivajući

Severinu gdje je bila dok su joj navodno zlostavljali dijete", In, 26. 10. 2019.

28 "Zbog Istanbulske ćemo postati robovi žena, one će biti iznad Sabora, sudova i države, SVEGA!" JL, 12. 4. 2019.

29 "Za razliku od Hrvatske, cijela regija je ratificirala konvenciju o zaštiti žena: Evo kakve promjene je donijela", In, 4. 10. 2017. odbijena, lažno optužuje (primjerice, u "Josipovoj kušnji": Post. 39:7-20) i raspamećene destruktivke u stilu Euripidovih Bakhi. GREVIO je pak metaforiziran kao feministička inkvizicija koja otima suverenost državi, neka vrsta nadnacionalne ruke feminističkoga ili čak "feminacističkog" klera. U intersekciji više diskursa koje prikazujem - identitarnoga, obiteljaškog, ali i republikanskoga i ekonomističkog - takvu je viziju najizravnije ponudio kolumnist Marcel Holjevac, služeći se epitetima s onu stranu političke korektnosti, tvrdeći kako ratifikacijom "Hrvatska dio svog suvereniteta predaje parareligijskoj, ideološkoj komisiji sastavljenoj od svećenica feminizma koje nitko nije birao, ali koje će krojiti zakone, nadzirati njihovu provedbu, proganjati homofobe i muške šovinističke svinje, i po potrebi paliti 'vještice' bilo kojeg spola koje se protive tome da kler femizma i rodne ideologije bude iznad zakona i Ustava, i da sve to još i plaćamo u iznosu u kojem one misle da treba":

"Radi se o tome da je GREVIO vid kulturnomarksističke inkvizicije sastavljen isključivo od žena jednog spola i raznih rodova. Seksizam, vrištale bi feministice kad bi postojalo kakvo međunarodno, naddržavno tijelo kojem bi suverene, demokratske države bile dužne po ugovoru plaćati reket a da pritom nikad nije razjašnjeno po kojim kriterijima se u njega biraju članovi, osim da su osobe 'visokih moralnih kvaliteta', kad bi to tijelo bilo sastavljeno od samih muškarca. I kad bi, ne daj Bože, bili katolici. Ili, da pojasnimo do kraja, Grevio prodaje oprost od grijeha onima koji daju dovoljno para za njihovu pravednu stvar. I zato je aktivistički kler toliko za konvenciju, a protiv toga da suverene države same to rješavaju, a sigurno to mogu učinkovitije od me- 
đunarodnog tijela. Tada bi oni ostali bez novca!"30

Priče o Remetincu koji je popunjen zbog pretjeranog broja optužbi za obiteljsko nasilje, u tom su diskursu pratili orvelovski scenariji političke represije uz propagandu i plastičniji scenariji o nepravdama koje će doživjeti muškarci u privatnoj sferi, dok bi se kontrafaktičke tvrdnje o statistički zabilježenom nasilju žena nad muškarcima katkad specificirale kao u javnosti potisnuta crna brojka psihičkog nasilja nad muškarcima. Prenosim tri komentara, od kojih su prva dva anonimna:

"Istanbulska konvencija je mizandrijski dokument koji ozakonjuje ekstremni feminizam jer IZRIJEKOM optužuje muškarce da potčinjavaju, dominiraju i čine nasilje nad ženama. Iako statistike govore sasvim nešto drugo, da su muškarci i žene podjednako nasilni, ratificiranje ovog dokumenta znači ozakonjenje lažne 'činjenice' da su muškarci listom nasilnici, a žene listom žrtve. S druge strane, Istanbulska konvencija IZRIJEKOM traži od država potpisnica da zanemaruju nasilje prema muškarcima i da svu pozornost da ženama. Ovo se vidi i u pitanju sakaćenja genitalija jer se spominje samo žensko sakaćenje, muško kao i da ne postoji. Naravno, ovo treba djeci utuvit u glavu od vrtića nadalje, zato Istanbulska konvencija i tu ima obaveze: 'od kolijevke pa do groba, muškarci su zli, a žene dobre, svima prat mozak'. Ako se usvoji ova konvencija, sutra će biti dovoljno da lokalni inkvizitor iz neke feminističke udruge, ili bilo tko, pomisli da BI SE MOGLO DOGODITI NASILJE, cijeli državni mehanizam nasilja prema muškarcu će se pokrenuti, ČAK i kad (potencijalna)

30 "Istanbulska konvencija iznad je Ustava, zakona, i demokratskih institucija - i koštat će milijardu kuna godišnje", Na, 19. 3. 2018. žena-žrtva svjedoči ili kaže da nasilja nije bilo! Zaboravite na povjerljivost u profesijama (liječnici, psihijatri i dr.) jer konvencija ukida povjerljivost u slučajevima pretpostavljenog nasilja. Muškarci će morati dobro pripaziti što kome govore u povjerenju e da policija ne bi zakucala na vrata $s$ lisičinama. Više muškarci neće smjeti ženi prigovoriti glede raspolaganja novcem jer to spada u 'financijsko zlostavljanje'. Pogađate, teška državna ruka 'pravde' će se spustiti na zlog i škrtog muškarca. Isto će se dogoditi ako po nečijem mišljenju muškarac ne privređuje dovoljno sadašnjoj i bivšim ženama, čime se legalno uvodi financijsko ropstvo za muškarce. Najstrašnije od svega, inkvizicija će se nastaviti do kraja bez obzira što tzv. žena-žrtva kaže, povuče prijavu ili bilo što. Sutra bilo tko može prijaviti bilo koga i državni feministički mehanizam će nemilosrdno samljeti sve na putu. Grdno se varaju oni koji misle da će ijedan zakon spasit svaku ženu od teških posljedica nasilja, ali će nanijeti nepopravljivu štetu većini europskih muškaraca, te muško-ženskim odnosima u cjelini". ${ }^{31}$

"Oženi ljenčugu, napravi joj dijete i ako joj slučajno prigovoriš da nije u redu da zuji po kući ili se ševi okolo dok ti krv pišaš na kakvom gradilištu, ona odmah zovne udrugu (kojih će biti kao gljiva poslije kiše pošto će konvencijom država morati propisanim iznosom financirati njihovo postojanje) i ti ideš u zatvor. Razvedi se od nje... e onda si tek nahebao. istjerat će te iz vlastite kuće i bit ćeš doživotni rob alimentacija i uzdržavanja... Ovo je jako pozitivan populacijski potez koji dečkima daje jasne smjernice... ševi ali ni za boga ne pravi djecu i

31 "Donosimo povijest ubojstava koja su zgrozila Hrvatsku", JL, 26. 2. 2017. 
ni u ludilu se ne ženi ili živi na istoj adresi". ${ }^{32}$

"Namjerna propaganda o zlostavljanju žena .Tvrdim da su muškarci u punom većem broju zlostavljani od žena, možda ne toliko fizički koliko psihički. Stotine zbog tog zlostavljanja svake godine počini samoubojstvo. Samo ja ih znam desetak koji su se ubili i nikad ni jedna žena nije zbog toga odgovarala pred sudom". ${ }^{33}$

Ta se pozicija također povezala $s$ naglašenim neprijateljstvom prema političkoj korektnosti koja se shvaća kao orvelovski novogovor usmjeren protiv istine: "Kao i svaki puritanizam, i politička korektnost, u ovom obliku, nehumana je, protuljudska, kulturocidna, nasilna, gdje se u ime slobode guše slobode, $u$ ime istine se guši istina, $\mathrm{u}$ ime nenasilja provodi nasilje... Doublethink, to je u jednom politička korektnost. Kada sam vidio da su Bizetu i remek-djelima svjetske kulture namijenili ulogu prema principu 'rat je mir, a mir rat', sasvim je jasno zašto je Carmen, žrtva, najednom postala ubojica, a ubojica, Don Jose, žrtva. Nije ni bilo moguće drugačije kada Bizet ovu operu nije uskladio s Istanbulskom konvencijom". ${ }^{34}$ Promjena radnje poznate opere iz navoda jest alegorija postpolitičkoga kulturnog pesimizma koji je ponudio diskurs o destruktivnoj vladavini žena kao naglašeno prisutan kontradiskurs anonimne internetske sfere.

32 "Branka Žigante Živković: 'Rodno utemeljeno nasilje vidi se u svakom sudskom spisu'", VL, 12. 3. 2018.

33 "300 ubijenih žena u 10 godina, 15.000 zlostavljanih žena godišnje, 184 posto poraslo obiteljsko nasilje... A HRVATSKA RASPRAVLJA O PITANJU RODA!?", JL, 7. 10. 2017.

${ }^{34}$ Ivica Šola, "Opera Carmen nije u skladu s Istanbulskom konvencijom", JL, 28. 1. 2018.

\section{Politika priznanja}

Diskurs priznanja ističe pak da je Konvencija dobra upravo zato što omogućuje razdvajanje zadanog spola i roda te posredno, zaštitom žrtava u kaznenoj politici, štiti rodne različitosti i otvara mogućnost promjene javnog jezika u obrazovanju i praksama zaštite od nasilja i kažnjavanju. Rod se shvaća kao pozitivna politička kategorija emancipacije raznolikosti i odbacivanja okova represivne tradicije. ${ }^{35}$ Konvenciju bi trebalo podržati zato što kažnjavanje povezuje s potlačenim identitetima koje je heteroseksistički i cisnormativni diskurs kroz svoje revne agente povijesno ubijao, mučio, psihijatrizirao i isključivao te međunarodnom obvezom najavljuje reviziju odgoja i obrazovanja gdje se, dovoljno rano, mogu iskorijeniti stereotipi i fobije prije nego što se povežu s toleriranim nasiljem. Konvencija je korak naprijed u povijesnom razvoju afirmacije različitosti. Zastupnici tog diskursa razumijevaju se kao progresivni, dok se za suparnike katkad koriste zaoštrene kulturološke i paleontologijske metafore krkana, pećinara i kamenog doba, kao što je i prvi diskurs nerijetko razumijevao svoje političke protivnike.

Diskurs priznanja upozorava na to da je ono što brine zastupnike zaštite obiteljske tradicije ionako već dio pravnog

35 Usp. objašnjenje konzervativnog protivljenja rodu: "Tome je vjerojatno razlog povezanost rodne teorije s pokretima koji promiču društvena i politička prava. Stoga uspostavu roda kao posebne kategorije neki doživljavaju kao političku opasnost jer se potkopavaju tradicionalni ustaljeni sustavi vrijednosti u skladu s kojima društvo funkcionira - kaže Ann Oakley, ne krijući svoje iznenađenje činjenicom da je rodna teorija i danas u 'nekim političkim režimima', pa i u Hrvatskoj, predmet napada i polemika". "JA SAM MAJKA RODNE TEORIJE. Iznenađena sam što i danas ima političkih režima u kojima se napada pojam roda. Vrlo je važno suprotstaviti se tim napadima", JL, 27. 3. 2018. 
sustava i javnih politika u Hrvatskoj, dok su njihovi strahovi postali predmetom oprečnih emocija izrečenih s dobrohotnoga paternalističkog pijedestala - zabave ("umirem od smijeha na vašu 'rodnoideološku minu'") i tuge zato što se država pokazuje nedoraslom zahtjevima nekovrsnoga izvanjštenog političkog superega koji će tolerirati spornu Interpetacijsku izjavu koja se ograđuje od rodne ideologije: "Ali, ako to umiruje nečiju savjest, nemam problema s tim. Vanjskopolitički učinak puno je problematičniji jer nas se doživljava kao neozbiljne. Tužno, ali sve zlo s tim", kako je istaknula profesorica ustavnog prava Sanja Barić. Ističući problem zaštite od nasilja nad ženama, ona je otvorila bitno veći prostor politici priznanja, koja je ionako u skladu s hrvatskim ustavnim poretkom i pravnom arhitekturom EUa, pa se zaštita rodnih identiteta može tražiti na višim instancijama:

"Na drugoj strani pitanje je rodnog identiteta koje se veže uz to što se pojedina osoba zbog svojih bioloških 'grešaka' osjeća da je rođena u krivom tijelu, a što je i medicinski pojam. Druga je stvar rodnog izražavanja $u$ smislu odijevanja, frizure... Konvencija se time ne bavi, već isključivo nasiljem nad ženama, i to uvjetovanim shvaćanjem društvenog položaja žene. A to što zabrinjava protivnike ratifikacije već postoji u našem poretku od 2009. u Zakonu o suzbijanju diskriminacije". ${ }^{36}$

Prakse ranog odgoja koji je u skladu s hibridnom diskursom Konvencije - organizirano rodno neutralan i tolerantan prema transrodnim identifikacijama i transvestitskim praksama - u tom se diskursu prikazivao afirmativno, ${ }^{37}$ suprotna

36 "Rodna ideologija izmišljeno je čudovište kojim konzervativci plaše javnost", VL, 19. 3. 2018.

37 "Taj proces upravo počinje u Seafarer vrtiću gdje djeca istrčavaju na dvorište u debelim strana prikazivana je kao "ultrakonzervativna", a novi odgoj i obrazovanje modernima kao u "normalnim zemljama". ${ }^{38}$ Zastupnici četvrtog diskursa nazivani su klerikalnima i "klerokonzervativnima",39 a retoričkim je pitanjem pripisivanje prijetnje marginalnim skupinama koje bi se moglo zaštiti označeno kao moralna panika: "Bi li se hrvatski svijet srušio da Konvencija doista štiti i tih stotinjak transrodnih osoba, koliko se procjenjuje da u Hrvatskoj ima onih koji se muče sa svojim rodom, i bi li to značilo masovnu transformaciju u rodno neutralni spol, suprotan biološkom?"40 Prigovor četvrtog diskursa kako nije riječ o liberalizmu nego o prisilnoj afirmaciji alternativnih rodnih identiteta uokvirivan je kao dio

odijelima za snijeg. Pod svojim odijelom, trogodišnji Otto nosi haljinu... Storesund se mora suočiti i s nekim dilemama u grupama. Primjerice, kad grupa dječaka od tri godine odbije crtati ili plesati i kad se čini da će se grupa podijeliti po rodnim ulogama, ona uskače da riješi problem potičući dječake da i dalje ravnopravno sudjeluju u aktivnostima. Očuvati rodno neutralnu okolinu nije jednostavno. Carina Sevebjork Saur (57), koja u školi radi već godinu i pol, kaže kako se često ulovi da kaže nešto neprimjereno, primjerice da udijeli djetetu kompliment na osnovu njegova izgleda". ("Kako su u Švedskoj odlučili da će odgajati djecu u vrtićima", JL, 30. 3. 2018).

38 Vilifikacija suprotnog pristupa i alarmizam bili su naglašeni makar koliko i u drugom diskursu: "Nikada do sada, niti jedan zakonski prijedlog ili ideja, nisu u sebi nosili toliku količinu maligne opasnosti za budućnost Hrvatske poput zahtjeva da roditelji odlučuju o tome što će učiti njihova djeca". "POBAČAJ JE UBOJSTVO, JASENOVAC KOMUNISTIČKI LOGOR, A ZEMLJA RAVNA PLOČA. Prođe li novi prijedlog Obiteljskog zakona, to će učiti mnogi hrvatski učenici", JL, 9. 4. 2018.

39 "Sarnavka i Markić burno raspravljale o Istanbulskoj konvenciji", VL, 6. 3. 2018.

40 "300 ubijenih žena u 10 godina, 15.000 zlostavljanih žena godišnje, 184 posto poraslo obiteljsko nasilje... A HRVATSKA RASPRAVLJA O PITANJU RODA!?", JL, 7. 10. 2017. 
politički opasne konzervativne revolucije, a za njezine zastupnike, ne samo u anonimnim komentarima, uvriježila se novokovanica "katolibani", koja označava one čiji je fundamentalizam usmjeren protiv rodne raznolikosti i liberalnijeg pristupa seksualnosti. ${ }^{41}$

Oruđe tog diskursa bio je humor feralovskog tipa koji uokviruje različite nemušte iskaze svjetonazorskih protivnika kao glupost, ${ }^{42}$ vlastiti politički stav kao prosvjetiteljsko raskrinkavanje, ${ }^{43}$ a suparnički kao teorije zavjere, ${ }^{44}$ ali se i izravno zgražava nad transfobnošću koja je s lakoćom prošla $u$ javnom prostoru, u figuri "brke" koji upada u ženske zahode, a u finijem registru diskursa u samu Interpretativnu izjavu oko koje se

${ }^{41}$ Usp. intertekstualni segment Stjepe Bartulice u tekstu Roberta Bajrušija: "U Hrvatskoj su mnogi samoproglašeni 'liberali' zapravo militantni sekularisti koji izgrađuju svoju poziciju postavljajući se protiv vjernika. Oni zapravo vide državu kao sredstvo za promicanje svoje agende, ali to nije liberalan stav nego pripada više duhu totalitarnih ideologija iz nedavne prošlosti". "PRVA PETOLJETKA HRVATSKE KONZERVATIVNE REVOLUCIJE. Počela je u prosincu 2012. godine... danas je Hrvatska znatno drugačija zemlja", JL, 16. 12. 2017.

42 "NAJLUĐE IZJAVE PROTIV ISTANBULSKE KONVENCIJE: 'To je đavolje djelo, zbog nje ljudi odlaze..."', In, 12. 3. 2018.

43 "RAZOTKRIVAMO ŠEST NEISTINA U LETKU KOJIM SE POZIVA NA ODBACIVANJE ISTANBULSKE KONVENCIJE. Od muškaraca u ženskim zahodima do 'bespolnih vanzemaljaca'", JL, 20. 3. 2018.

44 "Dakle, ne samo da je Vlada RH u izjavi koja prati međunarodni dokument legitimizirala i u službenom dokumentu ovjekovječila izmišljen i sadržajno prazan pojam rodne ideologije (koji u suštini demonizira transrodne osobe), već je Vlada transrodne osobe svrstala u kategoriju skrivenih namjera, a time Hrvatsku svrstala među države koje vjeruju u - teorije zavjere. Ne samo da nas je Vlada podsjetila na zlatno doba hrvatske homofobije, nego je to postavljeno kao naša vrijednost". Ivana Živković, "Istanbulska ruža vjetrova", Li, 30. 3. 2018. sklopila diskurzivna koalicija prvoga i četvrtog diskursa:

"Ne samo da nepostojeća 'rodna ideologija' odzvanja javnim diskursom sve snažnije i glasnije, nego ćemo ju, čini se, sad doslovce imati upisanu kao legitiman pojam uz međunarodni ugovor za sprječavanje i zaštitu žena od nasilja. Proteklih je mjeseci taj pojam korišten kao sredstvo širenja mržnje i gađenja prema transrodnim osobama i uistinu se radi, kako kaže Gordan Duhaček..., o najvećoj transfobnoj kampanji do sada u Hrvatskoj". 45

Interpretativna izjava nazvana je "istanbulskom krpicom" i metaforički ocijenjena kao "cipelarenje". Ocijenjena je i protuustavnom, pozivajući se na priopćenje Ustavnog suda u kojemu se poručuje da su u Hrvatskoj "spolni i rodni diverzitet zaštićeni Ustavom" (NN 138/2013), te politički podložna zloupotrebi za "daljnje zatiranje ljudskih prava". Uz protivljenje pojmu rodne ideologije ("pravno i akademski nepoznat i politički nedefiniran pojam"), društvena klima u kojoj je diskurzivna koalicija prihvatila Konvenciju povezana je sa širenjem "transfobne histerije od strane klerikalne desnice". U deklarativnom diskursu borbe za prava, nasuprot prvima dvama diskursima gdje su interpelirani subjekti bili žene izložene nasilju i oni koji s njima suosjećaju, odnosno potlačeni i obespravljeni muškarci, ovdje je to bilo raznoliko mnoštvo koje zahtijeva da se doseg Konvencije širi, a ne sužava: "Istanbulska konvencija najbolji je i najučinkovitiji pravni okvir za zaštitu žena od nasilja. Njezina svrha zaštititi je sve žene i sve obitelji od rodno uvjetovanog nasilja. To uključuje i trans žene, kao i životna partnerstva i njihovu

45 Jelena Tešija, "ZAGAĐIVANJE JAVNOG PROSTORA. Istanbulska, transfobija i homofobija", Li, 21. 3. 2019. 
djecu u partnerskoj i roditeljskoj skrbi". ${ }^{46}$ Izraženo je razumijevanje za aktivistice kojima je bolja bilo kakva konvencija, pa i s interpretacijskom izjavom, ali i jasno naglašene crte identitetskog raskola.

Diskurs politike priznanja nije bio rezerviran za internetske portale lijevog spektra, identitetske politike i zaštite manjina. Nasuprot prethodnom diskursu koji je dominirao anonimnim forumima, ali uglavnom nije stekao zastupnike u elitama, borba protiv diskriminacije, pa i pozivanje na njezin pravni progon u sklopu obuhvatne politike priznanja dobio je izraz u stranačkoj politici. Proširivanje ljudskih prava i zaštita homoseksualnih i transrodnih osoba bili su dijelovi saborskih i televizijskih rasprava, a branili su ih zastupnici najveće opozicijske stranke. ${ }^{47}$

46 Navodi u paragrafu preuzeti iz: "Poziv zastupnicima: Uklonite manipulativnu političku izjavu iz Zakona o ratifikaciji", $\mathrm{H}$-a, 11. 4. 2018. i "Uz Istanbulsku konvenciju servirana nam je transfobija i homofobija!", Li, 23. 3. 2018.

47 Usp. "Romana Jerković (SDP): (Uzdah) Kolegice, ako sam Vas dobro razumjela, a mislim da jesam, Vama smeta što je proširena kategorija obitelji i što sada imamo i neformalne životne partnere. Moram konstatirati da ne idete u korak sa zakonima koje donosimo. Donijeli smo Zakon o životnom partnerstvu, prema tome ovo (redefinicija obitelji u drugim zakonima) je logična posljedica toga. Morali smo uskladiti taj zakon (o zaštiti od nasilja u obitelji) sa ovim zakonom (o životnom partnerstvu). Meni je žao što Vi u ovome ne prepoznajete nečija ljudska prava i što, niste to jasno izgovorili, ali očigledno Vam to smeta". "(VIDEO) Esih: Stranka koja pristane na uvođenje termina 'roda' i redefiniciju obitelji, ne bi se smjela se zvati demokršćanskom", Na, 30. 1. 2017. (didaskalijski i pojašnjujući dodaci u zagradama preuzeti su iz izvornika). V. i izjavu Arsena Bauka u emisiji Otvoreno (HRT1, 22. 3. 2018): "Mnogo toga što je ovdje rečeno, moglo bi se podvesti pod članak Zakona o suzbijanju diskriminacije kao stvaranje ponižavajućeg okruženja prema osobama na temelju rodnog identiteta... Rodni identitet je zaštićen

\section{Obiteljska tradicija}

Diskurs borbe protiv rodne ideologije nastoji afirmirati heteroseksualnu obiteljsku tradiciju i odgoj djece u njoj. Tome vidi prijetnju u uvođenju transrodnih sadržaja i seksualnog odgoja u obvezne školske programe. Priznaje problem muškog nasilja nad ženama i ističe potrebu snažne borbe protiv te pojave, ali se protivi jeziku Konvencije. Njegovi zastupnici smatraju da se Konvencija nelegitimno miješa $u$ javne politike države uvođenjem kategorije transrodnosti, implicitno u definiciji roda i eksplicitno u nekim dijelovima teksta i objašnjenja. Krovna i najizražajnija metafora tog diskursa jest trojanski konj: lijep paket borbi protiv nasilja nad ženama ustvari je prijevara koja uvodi rodnu ideologiju u obrazovanje i javni diskurs te državi oduzima suverenost u odlučivanju o tim pitanjima, jer su međunarodni ugovori po pravnoj snazi iznad zakona. Diskurs obiteljske tradicije ponudio je i niz sličnih metafora, poput cigle u celofanu, a njegova opetovana, snažno psihologizirana metonimija bila je vinjeta o "sverodnim" javnim i institucijskim zahodima koje će pohoditi spomenuti brko, to jest perverzni silovatelj, predstavljajući se kao žena i tako ugroziti same žene. ${ }^{48}$ Strah

Zakonom o suzbijanju diskriminacije koji je donesen prije skoro 10 godina... Ali mi danas u tom zakonu još uvijek imamo odredbu da se stvaranje uvredljivog ili ponižavajućeg okruženja prema osobama na temelju rodnog identiteta prekršajno kažnjava 5 do 12 tisuća kuna. Mnogo toga što je ovdje rečeno bi se moglo u nekom smislu podvesti pod taj članak Zakona".

${ }^{48}$ Brko je dobivao impresivne opise: "Nabildani i bradati dvometraš u ženskome toiletu" (Davor Dijanović, "Tako mi Lalovca i Tomaševića, pročitao sam Istanbulsku konvenciju od početka do kraja i ponavljam zašto sam protiv", Dr, 18. 3. 2018). Premda snažno priziva psihoanalitičku interpretaciju, ta je figura bila taktički potrebna kako bi se žene prikazale kao žrtve Konvencije. 
od intruzije u klozet - načelno, dakako moguć, ali praktično neznatno opasan spram drugih rizika seksualnog napada ${ }^{49}$ - poprimao je karikaturalne razmjere. ${ }^{50}$ Taj je diskurs bio neskloniji kulturnom pesimizmu od drugoga, bio je borbeniji, ali je ratifikaciju i implementaciju Konvencije također povezivao $s$ pričom $o$ propadanju. ${ }^{51}$ Nasuprot drugom diskursu, nije prijetila opasnost od vladavine žena nego od posljedica rodne ideologije koja će kroz jezik, obrasce, kategorije i sankcije Hrvate pretvoriti u nešto

V. "Ivan Munjin: Žrtve Istanbulske konvencije su žene", $N a, 27$. 2. 2017. O problemu Brke u liku azilanata koji se lažno deklariraju kao rodno diskriminirani i kanadskih "manijaka u ženskim zahodima" v. Peti dan, HRT3, 15. 12. 2017.

49 Uz pokoju "izguglanu" anegdotu, ponuđen je i kvantitativni empirijski supstrat: "'U takvim zahodima je već zabilježeno oko 200 napada na djevojčice i žene... ', poručio je Glasnović". ("Nezavisni zastupnik o Istanbulskoj konvenciji: Čista perverzija!", JL, 12. 3. 2018).

${ }^{50}$ Pitanje zahoda postalo je doista dalekosežno: "Traženo spajanje muških i ženskih zahoda nije zaštita žena, nego propast civilizacije koju živimo od pamtivijeka". ("Profesor Marušić: Saborskim zastupnicima - četiri laži Istanbulske konvencije i rodne teorije", Na, 4. 12. 2017).

51 "Moje je ljudsko pravo da budem otac, ne roditelj 1 ili 2. Moje je ljudsko pravo nikome ne činiti zlo i zato mi ne nameći zlo. Istina, izlike, kad za primjenu IK moraš imati podršku svih medija, glavnih, Plenkovića i cijele oporbe, a cca $70 \%$ građana to ne želi onda se tu radi o diktaturi i to o diktaturi liberalizma, koji ce po prvi put u povijesti donijeti nazadak i propast onoga sto zovemo liberalna Europa..." (Komentar uz intervju: "Branka Žigante Živković: 'Rodno utemeljeno nasilje vidi se u svakom sudskom spisu'", VL, 12. 3. 2018). V. i istup Željke Markić u Temi dana, HRT1, 6. 3. 2018. Nije nedostajalo ni metaforike vezane za maligne bolesti: "Pojam roda se pritajeno uvodi u sve pore društva i zakonodavstava. I onda kad bukne, potrebne su kemoterapije i slični teški zahvati" (Komentar uz: "Zoran Šprajc pokušao 'spustiti' Bruni Esih - ona mu odgovorila", Na, 4. 10. 2018). nalik na "bespolne Kanađane". Leci su upozoravali na Pandorinu kutiju proliferacije rodova koju Konvencija otvara, a interpelirani subjekt bili su pripadnici naroda, napose katolički vjernici koji se trebaju boriti za zaštitu prava na ispovijedanje vjere i odgoj djece. Protivljenje Konvenciji imalo je različite izričaje, a artikulirano je u studiji bivše dekanice Pravnog fakulteta u Zagrebu (Hrabar 2018), koja je afirmativno prikazivana u pravničkima i teološkim časopisima.

Tipičan manevar tog diskursa u borbi protiv ratifikacije Konvencije bio je pristajanje na temeljnu poziciju prvog diskursa kako bi se dobio prostor za napad na Konvenciju. Za taj je manevar paradigmatska kratka prezentacija u letku o rodnoj ideologiji građanske inicijative Istina o Istanbulskoj, koja "oštro osuđuje svako nasilje nad ženama i nasilje u obitelji i zalaže se za što bolja zakonska rješenja u tom području i za njihovu učinkovitu provedbu", a zatim upozorava na "nametanje neznanstvene i propale rodne teorije". Tvrdnjom da bi ratifikacija Konvencije "ugrozila vrijednosti koje temeljno određuju hrvatski narod i time narušila njegov nacionalni, kulturni i vrijednosni identitet" smješta se na područje sljedećeg diskursa. ${ }^{52} \mathrm{Na}$ letku se djevojčica u suknjici i s kečkama pita je li muško ili žensko, razbijajući glavu nad školskim pitanjem, čime se sugerira da rodna ideologija postaje kurikularna obveza koja razara tradicionalni obiteljski odgoj koji, riječima prethodnog diskursa, uzima heteroseksualnost i cisrodnost kao zadane.

Zakašnjelo političko problematiziranje roda od strane zastupnika diskursa obiteljske tradicije opravdavalo se - $\mathrm{u}$ skladu $\mathrm{s}$ metaforom obmane $\mathrm{u}$ oblicima prošupljenog konja, zamotane cigle, krinke ili njihovih tautoloških

52 http://istinaoistanbulskoj.info/download/ letak.pdf 
gomilanja $^{53}$ - naknadnim shvaćanjem proširenja politike roda: "Bili su naivni i vjerovali su da je 'rod' sinonim za 'spol' - dok sada polako sve podvale koje 'ideolozi rodne ideologije' podmeću polako izlaze na vidjelo. 2008 i 2013 nismo ni sanjali da 'rod' nešto drugo znači nego 'spol' u kontekstu u kojem je pisano!"54 Prisutni diskurzivni lanci politički nabijenih označnica poslužili su za ironijsku afirmaciju vlastitoga tradicionalnog identiteta. ${ }^{55}$ Neke bi izvedbe povezale

${ }_{53}$ Također u intersekciji s ekonomskim naglascima i novijim pogrdnim nazivima za liberale u američkom smislu. Usp. navode: "Ukratko, ta konvencija je jedan trojanski konj pod krinkom zaštite žena od nasilja muškaraca kojom neoliberalna mafija nastoji progurati i ozakoniti svoju nastranu agendu i ideologiju jer su i njima dosadile tradicionalne 'parade ponosa'." "Ratifikacija sporazuma o promoviranju bolesne rodne ideologije, pod krinkom prava žena*. Well played, libtards". Navodi iz anonimnih komentara uz tekst: "Za razliku od Hrvatske, cijela regija je ratificirala konvenciju o zaštiti žena: Evo kakve promjene je donijela", In, 4. 10. 2017.

54 "Branka Žigante Živković: 'Rodno utemeljeno nasilje vidi se u svakom sudskom spisu'", VL, 12. 3. 2018. V. i anonimni komentar koji osporava sam pojam: "Sviđa mi se prijevod engleskog 'gender' u 'društveni spol'. To bismo i mi trebali prihvatiti, jer hrvatska riječ 'rod' (krvno srodstvo; gramatički rod) nikako nije 'gender'. Tako bi se pobornicima Ik i društvenog spola onemogućilo da zamagljuju pojmove i stalno tvrde kako je pojam roda već uveden u zakonodavstvo". "Zastupnici u Litvi smjeli objaviti zašto se protive ratifikaciji: Evo zašto je Istanbulska zaustavljena!", Na, 3. 4. 2018.

55 "Jesenti milu bigilicu, na bajnom HTV-u u svako doba dana i noći prednost imaju tzv. napredni, moderni, tolerantni, otvoreni, uključivi i antifašisti pred zna se kime - tzv. natražnjacima, zatucancima, zadrtima, ognjištarima i klerikalcima (inačica: klerofašistima), premda je ta druga skupina kudikamo brojnija i kao takva tzv. pretplatom uglavnom financira HTV". Komentar uz: "Gošća Nu2: Tko je Rada Borić, aktivistica i političarka koju Plenković stalno citira?", Na, 18. 3. 2018. prvi i treći diskurs kao nositelje političke korektnosti, a GREVIO odredile kao jednu u nizu "ideoloških policija". ${ }^{56}$ Teorijski najkoncentriraniju elaboraciju - cjelovit orvelovski scenarij kojim se suparnički diskurs politike priznanja nastoji usporediti s totalitarizmom - ponudio je kolumnist portala Direktno Matija Štahan, povezujući rodnu ideologiju s akademskom produkcijom rodne ideologije i njezinim političkim oblikovanjem jezika:

"Uzmimo za primjer idejno-vrijednosni sustav koji, u nedostatku boljeg termina, nazivamo 'rodnom ideologijom'. Riječ je o sklopu nepovezanih a srodnih fenomena utemeljenih $\mathrm{u}$ istome svjetonazoru, a koji - dekonstruirajući različite aspekte ljudskog identiteta i spolnosti - isprva nastoji promijeniti percepciju ljudskosti, da bi naposljetku iz temelja izmijenio bît čovjeka, pretvarajući ga u bespolno biće. Kao poluge 'rodne ideologije' služe discipline u rasponu od (post) feminizma do queer-teorije, ali vezujemo je i uz pojedine oblike New Age duhovnosti. Prva razina sličnosti 'rodne ideologije' sa starim rubno totalitarnim ideologijama ogleda se u propagandističko-cenzorskoj mašineriji nalik Goebbelsovoj, koja životne stilove na zasadama 'rodne ideologije' ne opisuje jednakovrijednima, već potiče kao poželjne, kako kroz kulturu i umjetnost, tako i kroz medijske linčeve neistomišljenika. Slje-

56 "Pripadnici i sljedbenici feminističko-LGBTTQI zajednice konačno su zauzeli ključne pozicije i sad predstavljaju mainstream politiku na Zapadu. Revolucija je na djelu, samo što se to danas zove društveni napredak, nastavni kurikul, borba protiv nasilja nad ženama i djecom i sl. Naime, živimo u svijetu političke korektnosti u sklopu koje govorimo politički korektno". ("Dr. sc. Hrvoje Pende: Dugi LGBTTQI marš kroz institucije Zapada ostvaruje svoje ciljeve - što će biti s Hrvatskom?", Na, 5. 4. 2018). 
deći korak u prilagođavanju društva pojedinoj ideologiji jest u suptilnoj, no korjenitoj preobrazbi jezika, u koji su se ušuljali mnogi novi pojmovi, ali i alternativne, 'nebinarne' zamjenice iz metajezika LGBT grupacija. Nakon gušenja kritičke misli slijedi pokušaj uništenja institucije obitelji te, posljedično, ideologizacija obrazovnog sustava. Na tragu komunističkoga "novog čovjeka" i nacističkog 'Übermenscha', i 'rodna ideologija' zastupa ideal svojevrsnog nadčovjeka. Taj se koncept ostvaruje na idejno-doktrinarnoj, ali i na praktičnoj razini; podvrgavanje adolescenata operativnim zahvatima promjene spola, čemu obično prethode i 'hormonske terapije', nije daleko od sumanutih eksperimenata doktora Mengelea, a gdjegdje je se ohrabruje i kroz obrazovni i zdravstveni sustav... Osim što joj nedostaje karizmatski vođa - i što još uvijek nije uspjela postati totalitarnom - ključna razlika između 'rodne ideologije' i starih totalitarizama jest i u činjenici da su oni primarno bili politički fenomeni, dok je 'rodna ideologija' multidisciplinarna. Nije hijerarhizirana niti institucionalizirana; ona se kapilarno širi mnogim ustanovama, od onih obrazovnih, poput najcjenjenijih sveučilišta, pa sve do političkih organizacija, stranaka i parlamenata različitih zapadnih zemalja". ${ }^{57}$

${ }_{77}$ Kolumnist uspoređuje klinike za pobačaj s logorima smrti, dok finale kulminira u transhumanističkoj distopiji. Jedan anonimni komentator potaknut tekstom, uz primjedbu o "financiranju iz iste blagajne" na tragu diskursa Protokola sionskih mudraca, poručuje da bi "novi Hitler" mogao "biti Drag Queen". ("Riječi, riječi, riječi; ili zašto hrvatskom društvu doista prijeti 'fašizacija"', Dr, 7. 4. 2018). Usp. i: "Oni koji to nisu u stanju bespogovorno prihvatiti i slijediti zavrjeđuju svaki oblik prokazivanja, prijezira, kazne i odbacivanja. Ako ne razumiju treba ih dodatno podučiti, ako i tada ne uspiju slijediti treba im interpretativno
U teorijski nesuptilnijemu i, općenito, prizemnijem registru, programatsko protivljenje Konvenciji u prijateljskom forumu možda je najjasnije izraženo u emisiji Bujica $^{58}$ u kojoj su gostovale Željka Markić i Ivana Foretić, a svaku od njih voditelj je predstavio kao majke četvero djece. U njoj je Konvencija proglašena "antikršćanskim, antivjerničkim, protuprirodnim dokumentom". Osim stava da "rodna teorija"59 koja se nameće Konvencijom postaje "ideologijom",

nalijepiti pečat sramote". ("Dr. sc. Zlatko Begonja: Bonobo poučak ili od zvijezde do roda", $\mathrm{Na}, 13.4$. 2018).

58 Bujica, Z1, 19. 3. 2018.

59 Kada se unutar tog diskursa katkad koristi izraz "teorija", nije namjera ojačati status diskursa i afirmirati ga kao znanost nasuprot ideologiji, nego ga diskreditirati kao nešto nepotvrđeno, ali načelno opovrgljivo. Usp. "Rodna teorija je iracionalna tlapnja. Ništa od onoga što ona govori ne samo da nije istina, nego je i notorna kontradikcija objektivnoj znanosti... Do danas je priča o izumitelju pojma 'rod' i njegovu zločinu nad dvojicom nesretnih dječaka zataškana. Krije se da je mengeloidni dr. Money izmislio taj koncept!" ("Profesor Marušić: Saborskim zastupnicima - četiri laži Istanbulske konvencije i rodne teorije", $\mathrm{Na}, 4$. 12. 2017). Vodeći svjetonazorski disident unutar HDZ-a, Davor Ivo Stier, u pismu koje su prenijeli svi mediji zauzeo je drugačiju poziciju prema kojoj je samorazumljivo da nije riječ o znanosti nego o političkom programu: "Naravno, ideolozi svake vrste će uvijek reći da oni zapravo zastupaju znanstvene stavove. I marksisti su smatrali da je ukidanje privatnog vlasništva pitanje ekonomske znanosti, a ne ideologije. Po definiciji, ideologija negira naravni poredak i želi stvoriti novu ideologiziranu realnost. A ako se činjenice ne slažu s takvim ideološkim pristupom - tim gore po činjenice. Tako je i s rodnom ideologijom. Ona tvrdi da rodni identitet može biti različit od spolnog identiteta. Po tome, žena može biti i onaj tko je biološki muško. Ako se biološke činjenice ne slažu s 'rodnim identitetom' - tim gore po činjenice". ("Stier u pismu HDZ-ovcima poslao prilično oštru poruku predsjedniku stranke Andreju Plenkoviću: 'To je uvredljivo i deplasirano..."', Dn, 12. 3. 2018). 
tvrdi se da se njome unosi "nesigurnost u identitet", što je "jako jedan ozbiljni problem za roditelje", ${ }^{60}$ kako je istaknula Markić. Problem je i to što novac odlazi "lijevo-liberalnim udrugama", o čemu odlučuje GREVIO gdje sjede zastupnice rodne ideologije. Uz bijes radi "seksualnih predatora", Foretić je obitelj metaforički shvatila u organicističkom ključu kao "stanicu svakog društva" i poantirala stavom da je agenda razaranja braka i obitelji, koju vode "ultraljevičarske feministice", put ka uništenju društvenog poretka: "Ako stanica nije živa, znamo da se društvo ruši". U nešto suzdržanijem istupu, Ivana Maletić, istaknuta članica HDZ-a, izrazila je skeptičnost prema čl. 14. Konvencije smatrajući da on "otvara prostor da se 'djecu u školama uči da je promjena spola normalna, da se curice potiče da se osjećaju kao muškarci i uvjerena je da to može zavesti određeni broj djece"'. ${ }^{61}$

Zagovaratelji Konvencije nazivani su "komunoidima", "leftardima", "genderistima", "lgbtejcima" i "ostalom kamarilom", ${ }^{62}$ u kreativnijim analogijama i "do-

60 Nasuprot prethodnom diskursu, rodna odgojna intervencija već u vrtiću izazivala je reakcije, od ozbiljne zabrinutosti preko neskrivene groze do ironije: "Vjerojatno gledaju politički korektne, nenasilne i rodno neodredive Teletubbiese". ("Dr. sc. Hrvoje Pende: Dugi LGBTTQI marš kroz institucije Zapada ostvaruje svoje ciljeve što će biti s Hrvatskom?", Na, 5. 4. 2018).

${ }^{61}$ Maletić se oprezno izrazila u žanru onoga što bi za zastupnike politike priznanja bila finija paternalistička transfobija, jer je unatoč iskazanoj ljubavi i ogradi od nametanja politika priznanja manjine većini konstatirala prethodne "probleme" nepolitičke naravi: "Njih treba s ljubavlju prihvatiti, ali protivim se tome da se njihovi problemi pretvaraju u univerzalne standarde - samo to i ništa više". "300 ubijenih žena u 10 godina, 15.000 zlostavljanih žena godišnje, 184 posto poraslo obiteljsko nasilje... A HRVATSKA RASPRAVLJA O PITANJU RODA!?", JL, 7. 10. 2017.

62 V. komentare uz: "Bauk i Škrabalo u mofobima", ${ }^{63}$ a u homonimnoj dosjeci "rodijacima" kada je riječ o članovima vladajuće stranke, "u novom značenju promicanja rodne ontologije i ideologije, zajedno s lijevom oporbom". ${ }^{64}$ Internetska proliferacija diskursa koji osporava rodnu ideologiju sugerirala je znatno organiziraniji pristup od razočaranoga muškoga kulturnog pesimizma iz drugog diskursa, a ratifikacija Konvencije i Interpretativne izjave pokazala je utjecaj diskursa obiteljske tradicije. Prije analize taktičkih i strateških aspekata procesa usvajanja Konvencije, valja ukratko prikazati i četiri sporedna diskursa koji su artikulirani u tom slučaju.

\section{Identitarno domoljublje}

Diskurs identitarnog domoljublja ratifikaciju i stupanje na snagu Konvencije nije primarno povezao s uništavanjem tradicionalne obitelji nego partikularne nacionalne tradicije: ne samo što će propasti heteroseksualna obitelj sa svojom podjelom uloga i odgojem djece, nego će ratifikacija olako potpisane Konvencije uništiti hrvatski narod koji se tijekom povijesti očuvao od tradicionalnih zavojevača dok danas pada pokoren od različitih "Facebook-hordi". U opasnosti je - to je differentia specifica toga spram drugoga i četvrtog diskursa - poseban hrvatski identitet izgrađen u povijesti. Problem je Konvencije, kako je to sročio saborski zastupnik Hrvoje Zekanović, "izvrnuti, naopaki sustav vrijednosti kojim se udara na temelje tradicionalnih vrijednosti hrvatskog društva". ${ }^{65}$ Taj diskurs plaši propadanjem - sisački biskup

Otvorenom prijetili antidiskriminacijskim tužbama", Na, 23. 3. 2018.

63 "SDP: Istanbulska konvencija je 'civilizacijski iskorak', 'klerikalni krugovi' vrše pritisak na premijera", Na, 24. 10. 2017.

${ }^{64}$ Nino Raspudić, "Istanbulska muka po Andreju Plenkoviću", VL, 9. 2. 2018.

65 "Ikone konzervativne scene: Evo zašto smo protiv Istanbulske konvencije", Tp, 13. 3. 2018. 
Vlado Košić kazao je da se u Hrvatsku Konvencijom uvodi "jedan sustav samouništenja"66 - ali i polaže nadu u otpornost naroda, čije "bilo" opipava Crkva "kako bi se snaga dobra usmjerila prema boljitku hrvatske domovine spominjući se nesebičnosti i žrtava podnesenih za slobodu i neovisnost". ${ }^{67}$ Politički stavlja naglasak na suverenost naroda, a političko-ekonomskoga i ideološkog neprijatelja označuje kao "šoroševski globalizam". 68

U diskursu identitarnog domoljublja "zagrmjeli" su, na sramotu svojih stranačkih nasljednika, i očevi utemeljitelji hrvatske države: "Krpina je spominjao da je cijela priča oko ratifikacije Istanbulske konvencije besmislena dok se u Hrvatskoj događa egzodus stanovništva u inozemstvo: 'Na što mi trošimo energiju? Na budalaštine! To je krajnje neodgovorno i neozbiljno prema narodu'". ${ }^{69}$ Taj se diskurs postavljao kao populistički i antiestablišmentski - u skladu s geslom "Za Hrvatsku i protiv ratifikacije Istanbulske konvencije, prava Hrvatska koja nije zastupljena u mainstream medijima"70 - ali je imao

66 VLt, 10. 3. 2019.

67 "Hrvatska biskupska konferencija: 'Protivimo se ratifikaciji IK i Interpretativnoj izjavi'", Na, 11. 4. 2018. V. i: "Istanbulska konvencija duboko poništava kršćanske korijene hrvatskog bitka", VL, 12. 3. 2018.

68 Usp. saborski istup Željka Glasnovića: "Ne trebamo takve uzore i trebamo krojiti svoju sudbinu i ugledati se na zemlje koje nisu satrapije Europske unije i globalnog pokreta, ovog globalizma a la mister Soros $\mathrm{i}$ njegovi kompanjoni ovdje u Hrvatskoj". U: "NAJLUĐE IZJAVE PROTIV ISTANBULSKE KONVENCIJE. 'To je đavolje djelo, zbog nje ljudi odlaze...', In, 12. 3. 2018.

69 "Jedan od utemeljitelja HDZ-a žestoko se obrušio na premijera. Cijela dvorana pljeskala, samo su Kalmeta i Kuščević šutjeli", JL, 20. 3. 2018.

70 Bujica, Z1, 19. 3. 2018. Bujančeve gošće, koje su programski predstavile prethodni diskurs, nisu osporavale voditeljevu ocjenu da je nakon pobjede u Domovinskom ratu nekoliko specifičnih otklona. Jedan je tradicionalni orijentalistički zazor koji je nastojao politizirati mjesto potpisivanja, Istanbul, te se nizom asocijacija projiciralo, slično kao u Houellebecquovu Pokoravanju, osvajanje političke vlasti, zajedno s ostvarivanjem brojčane prevage, od strane konzervativne i vitalne muslimanske populacije koja nadire u Europu. ${ }^{71}$ Možda je najbolje sažima sljedeći živopisan komentar Vjačeslava Ercega:

"Pistha mu mutherina! mi, vjernici, nismo za nasilje nad ženama, već smo protiv nasilja nad hrvatima, jer, za razliku od bespolnih kanađana, mi imamo očeve i majke i duboko smo uvjereni da homoseksualci ne mogu biti roditelji posvojenom djetetu! kao što je rekao dr ivo stier, mi, katolički vjernici, smo za dosljednu implementaciju sinajske konvencije koju smo potpisali u drugoj polovini sedmog stoljeća s papom agatonom". ${ }^{72}$

Specifično rasistički otklon, posebno politički neugodan u Hrvatskoj zbog povijesnog naslijeđa NDH, nije prezao

na snazi "unutarnja agresija" povezana sa snagama "liberalnog trulog Zapada". U sveopćem razumijevanju istomišljenika izjavljeno je da se Domovinski rat nastavlja, makar s malim slovom.

71 Usp. opet u kompilaciji novinara i društvenog komentatora Gordana Duhačeka: "'Žene u Hrvatskoj ne treba braniti na kapijama Stambola. U povijesnoj memoriji naroda kojima je Istanbul bio prijestolnica, žena se povezuje s haremom. A haremom se ne brane hrvatske žene'. (Kolumnist Marko Ljubić, 11. ožujka na portalu Narod. $h r$ ). 'S Turskom nas povezuju zulum, janjičari, danak, Mažuranić i Smrt Smail Age Čengića'. (Profesor na riječkom Pravnom fakulteta Nenad Hlača, 9. ožujka na portalu Narod.hr)" ("NAJLUĐE IZJAVE PROTIV ISTANBULSKE KONVENCIJE. 'To je đavolje djelo, zbog nje ljudi odlaze...', In, 12. 3. 2018).

72 "'Zar je katolička tradicija čuvanje tekovina nasilja?': Ima teologa koji i ovako misle o Istanbulskoj konvenciji", NL, 21. 3. 2018. 
od najkontroverznijih obrata vrednovanja i zlogukih projekcija s otklonom prema eshatologiji:

"Hitler i Himler su bili okultisti, ali su vjerovali u ideologiju rase i krvi. Bez djece i obitelji nema napretka za jedan narod, jednu rasu! Svjedoci smo da bijela kršćanska Europa odumire. I sad bi trebali podržavati ovu sotonsku rodnu ideologiju? Mogu se dva muškarca voljeti, ali ne mogu donijeti djecu na svijet! Brak, obitelj i majčinstvo treba biti iznad svega! Istambulska konvencija? Da nije žalosno bilo bi smješno! Turci su ovo prvi potpisali, ali je njihov sultan zagrmio pred narodom: Onaj tko ne rodi troje i više djece nije prijatelj ove zemlje, turskog naroda. Zna sultan što radi. Muslimani imaju po nekoliko žena. Ovo je namjenjeno anemičnim, jalovim zapadnjacima i njihovim ženama. Uskoro će nam trebat $\mathrm{i}$ pismeno odobrenje da im priđemo. A sve to platit će nas djeca, kad postanu rasna i vjerska manjina u Baalovoj Europi, Novog svjetskog poretka. Da zažališ što kotač povijesti 1945. nije prevagnuo na drugu stranu..."73

Metaforika je bila slična drugim diskursima koji se protive Konvenciji, naime ona bolesti i karcinoma, ali je glavni problem što će taj "libtardski karcinom" razoriti Hrvatsku ("Ako se budemo dovoljno dobro borili, možda uspijemo spriječiti metastaziranje karcinoma na Hrvatsku"74). Hrvatska je glavni vrijednosni označitelj toga diskursa. Kako je to postalo jasno iz specifikacije jednog prosvjednika u maršu protiv "Ikače",

73 Anonimni komentar uz: "Letica, Kuharićev poučak o Istanbulskoj konvenciji: kardinal bi je podržao i molio da zlo ne prevlada", VL, 19. 3. 2018.

74 Anonimni komentar uz: "U crkvi u Našicama dijelili letke protiv Istanbulske konvencije, pogledajte kakvim gadostima truju građane", In, 3. 1. 2018. kako su katkad protivnici nazivali Konvenciju, ako problem jest "pederčenje", tome je tako jer je posrijedi "pederčenje nacije".

Naposljetku, poziv na zaštitu nacionalnog identiteta koji interpelira narod kao etnos i zatim političku naciju, prema nasilju nad ženama odredio se romantizacijom tradicije: herojska figura kolumne Milana Ivkošića bila je hrabra žena koja je ostavila neodgovornog muškarca i "bila sretna kad je rodila sina". "I ne znam je li igdje kao u tim patrijarhalnim sredinama nasilnik koji je tukao svoju ženu bio tako omražen", pisao je Ivkošić, s čime feministice vjerojatno ne bi bile oduševljene. ${ }^{75}$ Premda je riječ o patrijarhalnoj kulturi koja ne haje za nacionalne granice, može se vrlo lako povezati s domoljubljem. Kao i moderniji konzervativizam kolumnista Mate Mijića, što ga je u komentarima pod tekstom izvjesni "mali Hrvat velikog srca" povezivao upravo s Hrvatskom i Domovinskim ratom jer je "domovina svetinja zato smo i najveći obol u Domovinskom ratu dali upravo mi. Sada ponavljaju istu grješku i preodgajali bi našu djecu. Zamislite ,peder i lezba da odgajaju plodove moje ljubavi (a imam ih hvala Bogu četvoro). Ne bu išlo. Neokomunisti mogu odgajati svoju djecu i govoriti im što je za njih dobro ,o vjeri i domovini ću ja učiti svoju djecu. Priroda (sazrijevanje za ljubavi sex) će učiniti svoje". ${ }^{76}$

\section{Radikalni ekonomizam}

Radikalni ekonomizam ne mora nužno biti marksistički, ali često preuzima marksistički trop baze i nadgradnje. Pitanje odnosa moći i promjena kažnjavanja, kao i identitetskih promjena, ustvari

5 "Hrabrost žena najsigurniji je spas iz nasilja u braku", VL, 27. 9. 2019.

76 Komentar uz tekst Mate Mijića, "Želja za prisilnim preodgojem tuđe djece do kraja raskrinkava hrvatsku ljevicu". VL, 16. 11. 2017. 
je pitanje promjena globalne ekonomije u kojoj su se na Zapadu u sklopu razvoja uslužne ekonomije i aktivnosti trećeg sektora smanjile razlike među muškarcima i ženama. Nestala je povijesna obitelj muškarca hranitelja koji je bio obiteljski suveren te zajedno sa stjecanjem novca u tvornici odlučivao i dijelio kazne. Identitarci okrivljuju lijevo-liberalne ideologe, ali zapravo je njihov model odnosa koji postoji u fantaziji romantičarske reakcije pojeo kapitalizam, dok su negdašnje dominacije obesmišljene razvojem ekonomije i tehnologije. $\mathrm{Pa}-$ trijarhalna tradicija za kojom se čezne samo je deplasirani romantičarski kič prevladane ekonomske reprodukcije života, kao i plemenska organizacija lova na mamute. On može opstati samo kao topli folklor, poput prazničkih inscenacija medijevalnih bitaka. Navest ću dva primjera, jedan općeniti i jedan sektorski, komentatora koje su potpisali "Severino Majkus" i Josipa Mučnjak:

"Postoje brojna i milenijska oblikovanja o zaštiti Žrtve od Predatora: pravna, moralna, vjerska, kulturološka, etička, ideološka. Devetnaestim stoljećem je napokon došlo i do njegovih teoretskih i korjenitih oblikovanja zasnovanih na skupnosti znanstvenih stečevina, koje nas upućuju na izvor svih društvenih jaza između Žrtve i Predatora. Dobro prekriveni, u klasnim čahurama pandorine kutije, i čuvani čuvarima stereotipnih Vračara, u šljemovima intelektualnog snoba i janjičarskim Spinovima. Sve kako bi se smetnulo s uma da odnos između Žrtve i Predatora biva direktno ovisan o društvenim odnosima dane povijesne epohe između načina ekonomske proizvodnje i njene razmjene. Bez razlike da li gospođa Dubravka Šimunović biva toga svjesna ili ne". ${ }^{77}$

7 "Hrvatska može spriječiti ubijanje žena, ali vlade su mi se žalile da im je to preskupo!", JL, 26. 2. 2017.
"Modna industrija je veliki biznis u kojem se okreće velika lova. Veliki mešetari su modni dizajneri. Modni dizajneri su u pravilu gender usmjereni. Mic po mic ovladali su svim generacijama i spolovima. I tako se pojavila žena u hlačama i muškarac u bermudama na cvjetiće. Dakle unisex. Danas je uobičajeno na sportskim terenima vidjeti kopačke žutih, crvenih, zelenih i narančastih boja. Poštujemo različitost (respect), a zapravo se provlači gender i s njom ono najbitnije - velika lova. $\mathrm{Na}$ kraju smo došli do Istambulske konvencije koja to polako treba ozakoniti i sve stavit pod 1 kapu. Jesmo li predugo bili kratkovidni ili kad je lova u pitanju ne vidimo dalje od nosa do očiju. Podnaški zažmirimo na sve". ${ }^{78}$

Modalnost ovog diskursa, kako pokazuju prizvana opća marksistička čitanka o ekonomiji i ideologiji i primjedba o političkom učinku ekonomije mode, jest eksplanatorna. Diskurs radikalnog ekonomizma nudi raščaranje ideološke magle i uzročno objašnjenje, izraženo u novijoj američkoj pragmatičnoj mudrosti "It's the economy, stupid!" Treba li reći da je taj diskurs bio izrazito slabo zastupljen, možda zato jer u njemu nije bilo velikoga političkog potencijala? Radikalnom ekonomizmu nedostajao je politički subjekt, osviještena klasa za sebe koja bi digla revoluciju. Ponekad se ekonomizam, u grubljim prozivkama, pojavljivao kao kritika partikularnih interesa i korupcije, ukazujući na ekonomski interes udruga i žena zahvaćenih Konvencijom, povezujući se tako s drugim i četvrtim diskursom. ${ }^{79} \mathrm{U}$ toj je

78 "Puljić: Vatikan priprema dokument o Istanbulskoj konvenciji; Pejčinović Burić: Nije RH jedina s ogradom", Dr, 23. 3. 2018.

79 Komentator sa slikom biskupa Košića i avatarom "Prskator.Vlado", koji je intuitivno razumljiv, poručio je: "... Bitno da se parazitira na državnu proračunu i vrišti o 
inačici ekonomizam razveden od ontologije ekonomskih klasa i tropa baze i nadgradnje te funkcionira u paradigmi racionalnog izbora individualnih maksimizatora koristi koji koriste diskurse i institucije da bi ekstrahirali ekonomsku rentu.

\section{Religijska eshatologija}

"Đavao raskola" - tako se, bez šale, može nazvati eshatološki diskurs o Konvenciji koji je upozoravao na isto ono što neki pristupi sociologiji rado prihvaćaju kao postulat - naime, da je u srcu društva sukob. Religijska bi se eshatologija mogla činiti tautologijom, ali kako postoje i eshatologije sekularnih ideologija koje projiciraju povijesne utopije, u politološkom radu to preciziranje ima smisla. U tekstovima pojedinih portala o Konvenciji, a posebno u komentarima, zazivalo se jedinstvo spolova nasuprot njihovu artificijelnom ratu i radu zlih raskolničkih sila koje djeluju kroz zavedene i pokvarene ljude. Eshatološka dimenzija diskursa, u temeljnom smislu nauka o posljednjim vremenima, bila je posebno izražena. Kao i uvijek, ta su posljednja vremena, u kojima se "svit konča", imajući u vidu razinu raskola i izopačenosti koja se politički nameće, bila ne samo blizu nego su se, sudeći po ocjenama, već počela događati.

Najbolji je dokaz bio politički raskol u hrvatskom društvu oko Konvencije, koja dodatno promiče razdor i opačinu. Radikalan i marginalan, taj je diskurs ipak bio značajnije zastupljen od prethodnoga te se nerijetko povezivao $s$ četvrtim i petim diskursom koji govore protiv nametanja rodne ideologije i zaštiti nacionalnog identiteta hrvatskog naroda. Moralističko naslijeđe maniheizma, koje se preko Augustina upisalo u

neravnopravnosti i potplaćenosti. 70\% žena drži kradosuđe" "Branka Žigante Živković: 'Rodno utemeljeno nasilje vidi se u svakom sudskom spisu'", VLw, 12. 3. 2018. kršćanstvo, strukturiralo je pojmovno polje tih istupa. Navest ću nekoliko primjera zlogukih suprotstavljanja što su ih ponudili anonimni komentatori na različitim portalima:

"Ne prijatelju, ti ne kužiš. Ja ne želim HOMOLGBT, NGO, liberalizam i ta shranja. Tu nije lijevo i desno, već sotonsko ili ljudsko..." ${ }^{80}$

"Ovaj svijet sve više postaje Sodoma i Gomora jer je narod napustio svoga Boga i priklonio se bajkama. Sve će nam se obiti o glavu jednog dana". ${ }^{81}$

"'Mržnja', suvremena floskula pod kojom se sotonski zakoni pokušavaju predstaviti kao kršćanski". ${ }^{2}$

"Oni koji ljube Isusa neće stati uz sotonu a to je Istanbulska konvencija". ${ }^{83}$

U pokušaju da se obnovi veza naroda i Boga, nerijetko se citirala Biblija: "Odakle Vam pravo da uzimate Ime Isusovo i dijelite lekcije iz Biblije. Na svoju sliku stvori Bog čovjeka, na sliku Božju on ga stvori, muško i žensko stvori ih. (Post $1,27)^{\prime \prime}{ }^{84} \mathrm{U}$ skladu s tom ontologijom spolova kao razdvojenosti koja je upućena na suradnju prema Božjem planu, rodna ideologija definirana je kao novo oruđe razdora koja prevladani sukob klasa prebacuje na još opasnije područje, udarajući na ono što je čovjeku najintimnije, a to je iskustvo spolnosti: "Kao i komunistička ideologija, koja je socijalne i društvene nejednakosti promatrala kao borbu među klasama, rodna ideologija promatra nasilje nad ženama kao

80 "U Hrvatskoj je puno cenzure, no sprečavanje širenja laži to nije", VL, 9. 12. 2017.

81 "Markić i udovice planiraju spriječiti glasanje o Istanbulskoj konvenciji u Saboru!", JL, 20. 3. 2018.

82 "FB: Petrijevčanin Vuksanović čestitala Uskrs - evo što su joj građani odgovorili", $\mathrm{Na}, 30.3 .2018$.

83 Isto.

84 Isto. 
proizvod sukoba među spolovima - kao da su muški i ženski spol međusobno suprotstavljeni, a ne komplementarni i upućeni jedno na drugo". ${ }^{85}$ Iako je interpelirani subjekt narod, ne kao etnička nacija nego kao potencijalno mistično tijelo, diskurs eshatologije diskurs je proročanstva koji ipak dijeli nešto $s$ grčkim mitovima, a to je nemogućnost izbjegavanja sudbine tog naroda i čovječanstva. Ta je sudbina religijski kodirana i vide je tek odabrani, a krajnja politika u potrazi za mirom srca u vremenima raskola jest - molitva krunice i obraćanje Gospi; dakle, umjesto prosvjeda - post. $^{86}$ $\mathrm{U}$ tom se registru pamtljivo javnosti obratio i mistični fizičar Davor Pavuna u Bujici, referirajući se na Konvenciju: "To je protuprirodno. Cijela priča pokazuje da mi živimo u Životinjskoj farmi. Svi smo mi jednaki, a neki su jednakiji". Ustvrdio je: "Oni razbijaju svjesno obitelj", a neke od specifikacija bile su "bankaroidi, u ime demona" i "EUSSSR". ${ }^{87}$

\section{Kazneni republikanizam}

Naposljetku treba izdvojiti republikanizam kažnjavanja koji se drži anakrone alegorije pravde $s$ povezom na očima i mačem u rukama. Njegova bi emička deviza glasila da svi subjekti moraju biti ravnopravni pred zakonom i javnim

85 "Ivan Munjin: Žrtve Istanbulske konvencije su žene", Na, 27. 2. 2017.

86 "Zadnja bitka između Boga i Sotone vodit će se preko obitelji i braka - riječi su to sestre Lucije dos Santos, vidjelice iz Fatime. Sestra Lucija napisala je to 1980. u pismu biskupu Bologne kardinalu Carlu Caffarru... Svatko tko se bude zalagao za svetost braka i obitelji bit će proganjan i diskriminiran jer to je ključno pitanje na kojem sve počiva. Ali, postoji lijek za obranu obitelji od Sotone..., dva posljednja sredstva (lijeka) protiv zla, a to su sveta Krunica i pobožnost Bezgrješnom Srcu Marijinu!" ("Fatimska vidjelica prorokovala: Sotona će napasti obitelj, ovo su dva posljednja sredstva za zaštitu!" Dn, 20. 3. 2018).

${ }^{87}$ Bujica, Z1, 12. 3. 2018. politikama, posebno kada je riječ o kažnjavanju. Republikanizam kažnjavanja upozorava na nepravdu koja se događa ako feministički aktivistički diskurs zadobije kontrolu nad kažnjavanjem tako što stare stereotipe mijenja novima i tendencijski stvara nove žrtve. Za razliku od diskursa o vladavini žena i identitarnog domoljublja, republikanizam ne zagovara patrijarhat, a promjene u kažnjavanju ne smatra prijetnjom nacionalnom identitetu. Pripadnici manjine trebaju biti zaštićeni kao pripadnici većine - ni manje ni više. Ustvari se drži jednakosti kažnjavanja kao temelja egalitarnog poretka koji nagrizaju razne neofeudalne intruzije što uvode nejednakosti u materijalno kazneno pravo i dovode u pitanje pravičan proces.

Kazneni republikanizam na tom području ne misli, kao Machiavelli u Vladaru, da je dolično fortunu usporediti sa ženom (koju treba krotiti i tući), nego zadržava poziciju dobrohotne vjere u zajedništvo koje se očituje kao kaznena neutralnost i jednakost pred dispozitivima kažnjavanja. On ne smatra da se od nasilja može obraniti partikularnim mehanizmima diskriminacije, ne pribojava se vladavine žena, ne zagovara proliferaciju politike priznanja u svim sferama javnih politika te univerzalnost povezuje s tolerancijom; njegova bi zaštita nacije trebala dati prostora razvoju manjina u okvirima univerzalne kaznene zaštite, politiku smatra odvojenom od ekonomije, a eventualnu vjeru u komplementarnost spolova ne povezuje s proricanjem apokalipse.

Pokušat ću taj shematski niz patetičnih projekcija koje lako mogu naći svoja negativna naličja - tko će štiti sve, ne štiti nikoga; mlaka pristojnost ne nosi rezultate u borbama moći itd. - trasirati u referentnomu diskurzivnom materijalu. Nekoliko isječaka iz komentara pod tekstovima, od kojih mnogi nisu anonimni, što sugerira spremnost da se javno 
brani pozicija te dolaze i uz muška i uz ženska imena, ponudilo je metafore endemske flore i faune, postavilo nasilje kao univerzalni označitelj i zagovaralo ideal građanske jednakosti, zajedno sa širenjem područja nasilja:

"A što smo mi u rangu velebitske degenije i čovječje ribice da nas treba posebno štititi? Tko će zaštititi muškarce, ili oni nisu ljudi?"88

"'Nasilje nad ženama i obitelji', molim lijepo, odbijam biti kriv po rođenju kao muškarac. Sloboda, jednakost i ravnopravnost je sastavni dio čl. 3. Ustava RH". ${ }^{89}$

"Ne postoji rodno utemeljeno nasilje. Postoji samo nasilje, utemeljeno na nasilništvu izvršitelja nasilja. Rodno ili bilo kakvo drugo nasilje utemeljeno na društvenim odnosima ne postoji. Ne postoji društveni status žrtve, kao ni društveni status nasilnika koji bi bio utemeljen na nekakvim društvenim ulogama, postoji samo odnos jači -slabiji". ${ }^{90}$

"Ma to je sve glupost. Nasilje bilo koje vrste (pa i verbalno) treba na odgovarajući način kazniti. Svejedno tko ga čini - nasilnike treba kazniti žrtve zaštiti. Za to ne treba nikakva konvencija... Dakle IK ništa neće postići, samo će produbiti razlike jer će ih pobrojati. Dok god državi nismo svi isti i dok god državu nije briga za svoje građane, dotle ništa od toga. Počnite razmišljati kako da država zaštiti svoje građane od nasilnika, a pri tome ne mislim samo fizičko nasilje, već i svaki drugi oblik nasilja". ${ }^{91}$

88 "Što je Istanbulska promijenila kod naših susjeda?", In, 23. 3. 2018.

89 Isto.

90 "Branka Žigante Živković: 'Rodno utemeljeno nasilje vidi se u svakom sudskom spisu'", VL, 12. 3. 2018.

91 "300 ubijenih žena u 10 godina, 15.000 zlostavljanih žena godišnje, 184 posto
Poruka jednakosti ponekad se formulirala $\mathrm{u}$ radikalnijim tonovima koje su ponudili internetski anonimci, ${ }^{92}$ a katkad bi se svela na ironičnu primjedbu "valjda i prema muškarcima". 93 Artikulirala ju je televizijska voditeljica Mirjana Hrga, izražavajući svoje protivljenje Konvenciji, ${ }^{94}$ a pozicija se povezivala $s$ drugima prikazanim diskursima, ipak više u desnome ideološkom spektru, ilustrirajući tako neobičnu sudbinu i upotrebe pojma jednakosti u hrvatskoj politici. ${ }^{95}$ Subjekt koji taj diskurs interpelira jest narod u smislu zajednice jednakih u javnim stvarima, uključujući kažnjavanje.

poraslo obiteljsko nasilje... A HRVATSKA RASPRAVLJA O PITANJU RODA!?", JL, 7. 10. 2017. Široko koncipiranje nasilja ne mora biti integralni dio kaznenog republikanizma s kojim se mogu povezati i kaznena umjerenost i kazneni oprez koji operiraju s užim definicijama nasilja.

92 "Ukinut ćemo ili izmijeniti sve zakone i propise koji predviđaju poseban - povlašteni - status za pojedine kategorije stanovništva: tzv. manjine, LGBTXYZŽNJ, pa i žene, jer praktično poništavaju građansko društvo. Još gore, valja to otvoreno reći: takvi propisi na mala vrata uvode apartheid, diktaturu manjine nad većinom, jer u građanskom društvu nema posebnih prava ni za koga". Komentar uz: "Mediji u službi politike: Jutarnji list plasirao lažnu vijest o vrtiću u Švedskoj i izjavama Željke Markić", $\mathrm{Na}, 9.4 .2018$.

93 "Dr. sc. Hrvoje Pende: Franjo Panj u Hrvatskom saboru", Na, 19. 4. 2018.

94 "Po čemu su žene važnije od svih njih?" "Ovakav estradni 'fajt' nije zabilježen: Jelena Veljača, Nevena Rendeli i Mirjana Hrga", Dn, 23. 3. 2018.

95 Usp. dio diskurzivnog lanca iz komentara "Hrvoja Horvata": "Ispiru mozak samo da bi vladali, nisu žene životinje da bi imali neki posebni zakon, ako smo svi jednaki pred zakonom to zagovaraju komunističke i antihrvatske udruge kako bi se uhljebile i crpile novce iz proračuna, treba jednom stat na kraj za svagda uhljebima..." "Crkva okreće leđa Plenkoviću? Svećenici pozivaju vjernike na prosvjed ispred HDZ-a", Mp, 20. 3. 2018. 


\section{Politička taktika sklapanja diskurzivne koalicije: kako su se zagovornici i protivnici rodne ideologije suglasili o nasilju nad ženama}

Dovoljno je iscrpno skiciran diskurzivni reljef koji se medijski ocrtao u vremenu ratifikacije, ponajviše krajem 2017. i u prvoj polovici 2018, da omogući razumijevanje političke igre unutar različitih institucija i arena, kao i izvan njih. Upozoravanje na nasilje nad ženama polučivalo je manju, ali u osnovi politički nemoćnu subverziju u kritikama da se Konvencijom uspostavlja vladavina žena. Politika priznanja bila je nedovoljno utjecajna da se nametne kao tumač Konvencije, no mogla je biti zadovoljna njezinim usvajanjem unatoč glasnim prigovorima zbog transfobije. Pravu je opoziciju usvajanju Konvencije ponudio diskurs obiteljske tradicije uspjevši iznuditi makar simboličan veto na ideološke promjene u pitanjima kurikularnoga i kaznenog priznanja rodne ideologije, što je ipak znatno slabije od ustavnog veta na širenje definicije braka 2013. On se povezivao s domoljubljem, ali simboličko utočište nacije nije bilo presudno u igri diskursa, kao ni povremeni apolitični ili nemoćni uplivi posljednjih triju prikazanih diskursa. No kako se točno oformila koalicija prvoga i trećeg diskursa koja je omogućila ratifikaciju koja je ispod velike ideološke borbe propustila partikularističko zaoštravanje kaznene politike?

$\mathrm{Na}$ razini izvaninstitucionalne politike, prosvjednih kretanja i civilnog društva, usvajanje Konvencije podržao je prosvjed "Sluškinje ustaju za ratifikaciju Istanbulske", koji je okupio nekoliko desetaka aktivističkih performerica u odorama koje su skrušeno prošetale Zagrebom. ${ }^{96}$ Održana su i dva prosvjeda

96 "Prosvjed za Istanbulsku konvenciju: 'Nismo sluškinje i nikada nećemo biti'", VL, 10. 2. 2018. protiv Konvencije, u Zagrebu 24. ožujka 2018. i Splitu 12. travnja 2018, koji su antagonizirali predsjednika Vlade i zagovornike Konvencije unutar vladajuće stranke kao karijerističke i nevjerodostojne "plenkiste". ${ }^{7}$ Skupove su obilježile drastično različite procjene broja prosvjednika od strane organizatora, policije, različitih udruga i medija, ${ }^{98}$ koje su se kretale od nekoliko tisuća do nekoliko desetaka tisuća, a da se ne govori o oprečnim vrijednosnim etiketama koje su opetovano ilustrirale inventivnost diskursa o društvenim događanjima. ${ }^{99}$ Građanska inicijativa Istina o Istanbulskoj organizirala je prikupljanje potpisa za referendum protiv Konvencije te je u lipnju 2018, nakon dva tjedna prikupljanja, predala više od 390.000 potpisa, ali je Ministarstvo uprave u postupku provjere $\mathrm{u}(\mathrm{s})$ tvrdilo gotovo 45.000 nevažećih potpisa, na što se inicijativa u rujnu 2019. žalila Ustavnom sudu, a postupak je u vrijeme zaključivanja ovog članka još bio u tijeku. Cijelo se medijatizirano civilno društvo uoči odluke o ratifikaciji uključilo u raspravu. Hrvatska akademija znanosti i umjetnosti izdala je priop-

97 Nino Raspudić, "E moj druže istanbulski", VL, 30. 3. 2018.

98 Usp. "Zašto Božinović broji samo neke javne skupove - i to krivo?", Na, 23. 10. 2019. "Poslao sam redakciji sa zapadne strane Trga Bana Jelačića sliku iz koje se vidi masa od nekih 70.000 do 80.000 prosvjednika. Navodno je za Jutarnji brojao Boris Vlašić, a za Večernjak Branimir Pofuk. Kad su došli do pet tisuća otišli su u Gradski podrum na srpski pasulj". (Zvonimir Hodak, "Prodali smo dušu vragu i sve će na kraju i otići k vragu...", Dn, 26. 3. 2018); "Desetci tisuća okupljenih u Splitu: 'Podignite ruku PROTIV ratifikacije Istanbulske konvencije i zaštitite narod'", Na, 12. 4. 2018.

99 "Najavljivani velebni svehrvatski skup u centru Zagreba na kraju je izgledao kao polupropali seoski kirvaj, debakl nakon kojeg im se svi normalni ljudi u Hrvatskoj smiju i rugaju." Gordan Duhaček, "Primitivna manjina najavljivala spektakl, a prosvjed ispao debakl", In, 24. 3. 2018. 
ćenje protiv Konvencije u prosincu 2017, a Biskupska konferencija u ožujku 2018. $\mathrm{Na}$ javnoj su se televiziji, u nekovrsnom dvoboju titanskih matrijarhinja s različitih polova ideološkog spektra civilnog društva, sučelile Željka Markić i Sanja Sarnavka, ${ }^{100}$ dok je voditelj Bujice metonimijski poručio zastupniku HDZ-a Josipu Đakiću, koji je odlučio podržati Konvenciju, da zamijeni žute zenge štiklama. ${ }^{101} \mathrm{U}$ televizijskim emisijama raspravljali su predstavnici stranaka, ${ }^{102}$ na marginama velike društvene rasprave stavove su iskazali i predstavnici ostalih vjerskih zajednica, ${ }^{103}$ a ratifikaciju su

${ }^{100}$ Tema dana, HRT1, 6. 3. 2018.

${ }^{101}$ Bujica, Z1, 19. 3. 2018.

${ }^{102}$ Hrvoje Zekanović iz HRAST-a predložio je da se u Konvenciji rod zamijeni spolom i da se postrože kazne za nasilnike u obitelji pa će "demagogija pasti u vodu". Romana Jerković iz SDP-a tvrdila je da, kao socijaldemokratkinja, ne smije nametati svoj svjetonazor i da svima treba dati slobodu da žive svoj svjetonazor (Otvoreno, HRT1, 8. 3. 2018). Dubravka Šuica je nekoliko dana kasnije izjavila da je slučaj ratifikacije Konvencije pokazao pluralizam u HDZ-u, kao $\mathrm{i}$ to da "nema nikakve rodne ideologije u Istanbulskoj konvenciji" (Otvoreno, HRT1, 12. 3. 2018).

${ }^{103}$ Predstavnici židovske i protestantske (baptističke) vjerske zajednice Konvenciju su podržali, ističući nasilje nad ženama kao problem, ali su odbacili rodnu ideologiju. I predstavnici ostalih vjerskih zajednica pristali su na diskurs o nasilju nad ženama. Predstavnik Srpske pravoslavne crkve bio je nešto skeptičniji, makar u pogledu na implementaciju, dok je predstavnik Islamske zajednice istaknuo: "Što se tiče Istanbulske konvencije, ako ona dozvoljava promjenu spola bez liječničke potvrde, islamska zajednica smatra da treba zadržati onaj spol koji je dobila prilikom rođenja. Muslimanski učenjaci prilikom donošenja neke odluke ili mišljenja, vode se onim da je ispravno onim što je veća korist od štete da se ona može dozvoliti pogotovo ako je u pitanju zaštita žene ili zaštita njenog digniteta, ponosa ili časti". Katolički je predstavnik također podržao borbu protiv nasilja nad ženama, ali ne i Konvenciju, u skladu sa stavovima Biskupske konferencije. podržale i brojne osobe s estrade, što je potaknulo i lakonski protukomentar "ne za instagramsku". ${ }^{104}$

$\mathrm{Na}$ razini institucionalne politike, HDZ se našao u svjetonazorskom raskolu pod pritiskom snažne politizacije Konvencije, koja je ranije bila pasivni pa i podpolitički dio opće fraze stranačkih programskih dokumenata. Oporba se pak našla u neugodnu položaju: zbog ideoloških razloga morala je usvojiti ono što zagovarala vlast koja Konvenciju, prema uvriježenima ideološkim koordinatama, ne bi trebala podržati. ${ }^{105}$ Predsjednica se također našla u nevolji između međunarodnih očekivanja i podilaženja vlastitome biračkom tijelu pa je, podržavši Konvenciju, zaključila kako će Interpretativna izjava "ukloniti dvojbe o određenim dijelovima Konvencije". ${ }^{106}$ Rada Borić je pak metonimijski primijetila da "iznad popa ima Bruxelles", ${ }^{107}$ a u danom je slučaju tako i bilo.

Stierovo svjetonazorsko oponiranje ocijenjeno je u novinama kao "epistolarna disidencija": "Krajnji cilj svega što Davor Stier radi u politici upravo je da to

"VJERSKE ZAJEDNICE: Evo tko je za, a tko protiv Istanbulske konvencije", Dr, 19. 3. 2018. Oprečan stav unutar Katoličke crkve u Hrvatskoj v. u: "Zar je katolička tradicija čuvanje tekovina nasilja? Ima teologa koji i ovako misle o Istanbulskoj konvenciji", NL, 21. 3. 2018.

104 "FOTO: SEVERINA, MINISTRICA DIVJAK, ANA GRUICA, LUKA NIŽETIĆ... UDRUŽILI SE U JEDNOM CILJU: Ako želite da se ratificira Istanbulska konvencija...", JL, 20. 3. 2018.

105 "Unesu li se iznimke koje se odnose na pojam rod, GLAS i IDS će biti protiv", JL, 13. 3. 2018.

106 "Predsjednica konačno iznijela stav o Istanbulskoj konvenciji", VL, 22. 3. 2018.

107 "Gošća Nu2: Tko je Rada Borić, aktivistica i političarka koju Plenković stalno citira?", Na, 18. 3. 2018. 
nikad ne mora učiniti". ${ }^{108}$ Konformizam unutar HDZ-a nazvan je "robnom ideologijom": "...Njima je to samo još jedna, tko zna koja prilika da drmaju državni orah funkcija, poslova, utjecaja i novca ne bi li s njega palo što više za njih." ${ }^{109}$ To što su zagovornici Konvencije u HDZ-u nazvani nenačelnim "ćatolicima", ${ }^{110}$ nije ih znatnije uzdrmalo. Realpolitički gledano, odustajanje od dominantnog diskursa borbe protiv nasilja nad ženama značilo bi prepuštanje političkog profita na tom području oporbi. Premijer je kazao kako je bilo "nužno preuzeti inicijativu na polju zaštite žena od nasilja kako bi se spriječilo da oporba i ljevica monopoliziraju tu temu", ${ }^{111}$ čak i ako je to značilo da se ideološki gledano "nakon SDP-a, eto, i HDZ... pretvara u HNS". ${ }^{112}$ Predsjedništvo HDZ-a prihvatilo je ratifikaciju Konvencije s 19 glasova "za" i šest "protiv". ${ }^{113}$ Podržali su je i HDZ-ovi koalicijski partneri. Vlada je Konvenciju usvojila jednoglasno.

Uslijedila je diskurzivna prezentacija politike kao autoriziranog izbora: "Slanje $\mathrm{u}$ proceduru ove Konvencije nije plod pritiska oporbe ili građana, već je to čvrsta i jasna volja moje Vlade da ratificiramo dokument koji se temelji na našem programu, radu međuresorne skupine, postignutog čvrstog uvjerenja da

${ }^{108}$ Marko Biočina, "Kalkulantska disidencija HDZ-ova političkog tajnika", JL, 15. 3. 2018.

${ }^{109}$ Nino Đula, "Ne vjerujete valjda da se protivnici Istanbulske bore protiv tog dokumenta zato jer ih muči rodna ideologija? Jasno je koji je pravi razlog!" JL, 22. 3. 2018.

${ }^{110}$ Nino Raspudić, "Istanbulska muka po Andreju Plenkoviću", VL, 9. 2. 2018.

111 "DETALJI DRAME U HDZ-u. Plenković prijetio rušenjem Vlade: 'Možda pola vas više ne bude na listama'", NL, 13. 3. 2018.

112 "Ivan Hrstić: HDZ na operaciji promjene političkog spola", $\mathrm{Na}$ (preneseno iz VL-a), 22. 3. 2018.

113 "Predsjedništvo HDZ-a podržalo Istanbulsku. Doduše, Plenković ima jaku oporbu u stranci", Tg, 20. 3. 2018. će ratificiranje ove konvencije osnažiti pravni, institucionalni i financijski okvir za rješavanje problema koji se zove - nasilje u obitelji - nabrojao je Plenković". Premijer je odmah ponudio objašnjenje sadržaja Interpretativne izjave odbacivši mijenjanje institucije braka i (u množini) "promjene u rodnim ideologijama": "Nema pravne obveze za priznanje trećeg spola, nema ni za redefiniciju braka, nema pravne obveze za uvođenje u školske programe nešto što možda nije u skladu s našim uvjerenjima". ${ }^{114}$ To je bio nužan ustupak konzervativnoj struji stranke i pritisku četvrtog diskursa o zaštiti obiteljske tradicije.

U Saboru je Plenković citirao statistike o nasilju nad ženama, odbacio stav da je GREVIO "bauk" i rekao da se u sklopu Nacionalne strategije zaštite od nasilja u obitelji neće izdvojiti milijarda kuna nego 70 milijuna od 2017. do 2022. Ratifikaciju je podržao i klub SDSS-a, a Milorad Pupovac objasnio je taj potez "obvezom braka da se gradi kompromis". Ratifikaciju su podržali i IDS,

114 "VLADA USVOJILA ISTANBULSKU KONVENCIJU. Ustavna stručnjakinja: 'Neće biti neočekivano ako Hrvatska zbog ove izjave bude snosila političke posljedice'", JL, 22. 3. 2018. Usp. i: Iva PuljićŠego, "Premijer će se izjavom ograditi od pitanja roda i rodne ideologije", VL, 10. 3. 2018; "Puljić: Vatikan priprema dokument o Istanbulskoj konvenciji; Pejčinović Burić: Nije RH jedina s ogradom", Dr, 23. 3. 2018. Interpretativna izjava nije uvjerila konzervativce koji su vidjeli ono što vide, a svoje neslaganje izrazili su bogatom metaforičkom imaginacijom: "Taj dodatak podsjeća na Magritteovo slavno djelo: 'Ovo nije lula'. Slikar je realistično prikazao lulu ispod koje piše 'Ceci n'est pas une pipe', dakle 'ovo nije lula', tj. tvrdi se kako to nije ono što nam se čini. Magritteova slika potiče brojne interpretacije... Plenkovićevom interpretativnom izjavom se konstatira kako u Konvenciji nema rodne ideologije što je, otprilike, kao da popijem čašu viskija uz konstataciju kako u njemu nema alkohola". ("Plenkovićev nadrealizam ili 'ovo nije lula", VL, 23. 3. 2018). 
HSS, GLAS, HSU i HNS, navodeći važnost zaštite žena, pozivajući se na modernost i iskazujući podršku različitosti. Konvenciju su podržali i HSLS i HDSSB, ali ne i HDS. Neovisni za Hrvatsku i Hrvoje Zekanović iz Hrasta bili su protiv. ${ }^{115}$ MOST i Živi zid bili su podijeljeni: ${ }^{116}$ prva je stranka dala jednog zastupnika od onih koji nisu glasovali, iako su bili u sabornici kada se odlučivalo o ratifikaciji Konvencije, a druga trojicu. SDP je bio "za", uz naglašeno moralističko pristajanje na prvi diskurs, dok se ranije deklarirana načelna oporba iz mladeži stranke, čije su perjanice ponosno preuzele etiketu "rodnih ideologa" koji nikad ne vjeruju Plenkoviću, istopila. ${ }^{117}$

Od niza malih taktika i previranja u predvidivim okvirima na razini institucionaliziranih političkih elita, zanimljivija je diskurzivna koalicija koja ih je omogućila. Ona je definirana u društvenom procesu tvorbe diskursa povezanog s civilnima društvom i medijima koji je definirao okvire političke rasprave i ponudio taktičke elemente koji se mogu povezati. Diskurzivna je koalicija izraz dominacije diskursa o nasilju nad ženama i njezina kompromisa s obiteljskom

115 Podrobnije o raspravi: "Hasanbegović: Zaštita žena je samo smokvin list. Bauk: Križari ne podnose slobodu", VL, 11. 4. 2018. Točan popis dostupan na: "PREMA RASPOREDU SJEDENJA. Istanbulska konvencija: Evo tko je bio protiv, tko suzdržan, a tko se nije ni pojavio", Dr, 13. 4. 2018.

116 Slavica Lukić, "GLASANJE O ISTANBULSKOJ PODIJELILO I ZASTUPNIKE MOSTA I ŽIVOG ZIDA Doznali smo koji će njihovi zastupnici biti za, a koji protiv konvencije", JL, 14. 3. 2018. Usp. i ranije istupe čelnika Živog zida: "'Kad sam vidio šok na licu Bunjca, bilo mi je jasno što se događa u Agrokoru. Ja sam za Istanbulsku konvenciju, nedavno mi se rodila kći'", JL, 26. 11. 2017.

117 "RASLOJAVANJE U SDP-u: 'Nećemo biti za Istanbulsku ako uz nju budu išle rezerve i ograde' UTJECAJNA ZASTUPNICA 'Glasat ću ZA pa kome pravo kome krivo'", JL, 20. 3. 2018. tradicijom. Momente te diskurzivne koalicije na razini institucionalne i izvaninstitucionalne politike možda najbolje izražavaju upravo Stierovo pismo i izjava Nina Raspudića na zagrebačkom prosvjedu protiv Istanbulske konvencije:

"Kršćanski demokrati u Hrvatskoj zauzimaju se za poštivanje digniteta žena i djevojčica, apsolutno su za borbu protiv nasilja, ali ne prihvaćaju postulate rodne teorije na kojima počiva Istanbulska konvencija. To, pak, ne znači da ne mogu raditi sa liberalima i pobornicima drugih ideologija (unutar EPP-a, HDZ-a ili bilo koje druge stranke) u zajedničkim naporima u borbi protiv nasilja nad ženama. Na primjer, kršćanski demokrati bi trebali podržati povećanje financijskih sredstava u proračunu za ovu plemenitu svrhu, bez obzira što se protive ratifikaciji Istanbulske konvencije. ${ }^{118}$

"Novinarka: Evo samo za kraj, što se tiče nasilja nad ženama u Hrvatskoj, složit ćete se da je to dosta veliki problem. Mislite li da tu Istanbulska konvencija može pomoći?

Nino Raspudić: Mislim da je to pitanje uvredljivo i potpuno izlišno, dakle nitko ne dovodi u pitanje nasilje nad ženama, mi znamo što je problem i o čemu razgovaramo. Takva pitanja smatram podmetanjima jer to nikome nije sporno". ${ }^{119}$

Gramšijevski rečeno, prvi je diskurs ostvario hegemoniju koja se izražava kategoričkim modalitetima, patetičnom frazom i konstatiranjem samorazumljivosti. Raspudić se, ustvari, suglasio sa

\footnotetext{
118 "Stier je u pismu HDZ-ovcima poslao prilično oštru poruku predsjedniku stranke Andreju Plenkoviću: 'To je uvredljivo i deplasirano...', Dn, 12. 3. 2018.

119 "Nino Raspudić sudjelovao na prosvjedu protiv IK: Evo kako je pojasnio glavne probleme!", Na, 26. 3. 2018.
} 
Sarnavkom i Nevom Tolle o nasilju nad ženama, a još više s Dubravkom Šimonović koja je prihvatila Interpretativnu izjavu kao opravdanu. Da je ta koalicija bila doista široka još je jednom u povijesti hrvatske kaznene politike dokazao predsjednik HDSSB-a Branimir Glavaš. Glavaš, koji je svojevremeno bio protiv uvođenja kazne doživotnog zatvora i općenito zastupa progresivnu poziciju o kažnjavanju, makar kada je riječ o saborskim istupima protiv penoloških neopravdanih postroženja službene kaznene politike, kategorički je otpisao nevolje s rodom. Glavaš je, naime, istaknuo "da je Istanbulska konvencija dio predizbornoga programa HDZ-a i treba ju ratificirati, dok je javnu raspravu o Konvenciji okarakterizirao kao čistu histeriju". ${ }^{120}$ Njegovu antiklerikalnu besjedu vrijedi zabilježiti: "Hrvatska je sekularna država i HDSSB želi da i u budućnosti ostane sekularna država. Jasna, precizna i nedvojbena odvojenost crkve od države je regulirana Ustavom. Zalažemo se da te vrijednosti ostanu trajno zabilježene u hrvatskom Ustavu te da se hrvatski građani i pojedine institucije pridržavaju te ustavne odredbe". ${ }^{121}$

Istanbulska je konvencija usvojena. U javnosti je pak ostala oprečan simbol. Protivnici su u svakome novom slučaju nasilja nad ženama vidjeli opovrgavanje Konvencije, ironizirajući njezinu djelotvornost, dok su zagovornici u njoj vidjeli važan korak u podizanju svijesti o problemu nasilja te su strožije kažnjavanje nasilnika smatrali posljedicom Konvencije kojom je država počela preuzimati odgovornost za društveno nasilje nad ženama:

120 "Hasanbegović: Zaštita žena je samo smokvin list. Bauk: Križari ne podnose slobodu", VL, 11. 4. 2018.

121 "BRANIMIR GLAVAŠ STAO U OBRANU SEKULARNE DRŽAVE. 'Crkva od države je jasno, precizno i nedvojbeno odvojena, glasat ću za Istanbulsku bez ikakvih uvjeta"', JL, 20. 3. 2018.
"Nemojte komentirat (a još manje kritizirat) stvari koje ne razumijete. Istanbulska konvencija ne može osigurati da na svijetu više ne bude nasilnika, već da oni budu primjereno kažnjeni, a ako i ne budu, da država za to odgovara. IK je pravni okvir koji će, s vremenom, pokazati rezultate. Vi ste mislili da će odmah nakon ratificiranja svi nasilnici prestat biti nasilni? Vidite, to što je onaj Daruvarac dobio pet godina bezuvjetnog zatvora, e TO je Istanbulska konvencija na djelu. Takvih će stvari biti sve više, a slučajeva kad netko premlati ženu pa mirno ode na tekmu sve manje. Ali ništa se neće dogoditi preko noći kako vi valjda mislite da bi trebalo i da je moguće". ${ }^{122}$

Portali su nastavili pratiti protagoniste njezina usvajanja, Konvencija se pojavila i kao ulog predsjedničke kampanje, ${ }^{123}$ dok su nastavljeni sporovi suprotstavljenih ideoloških polova civilnog društva o tome povećava li se nasilje zbog rastakanja obitelji ili je ono sâmo razara. ${ }^{124} \mathrm{U}$ političku je povijest pak odlazio proces njezina usvajanja unutar skicirane diskurzivne križaljke. Konvencija je ratificirana formiranjem diskurzivne strategije iz racionalnosti samih taktika i njihovim kombiniranjem na polju realne politike. Strategije vlade o kaznenoj politici o pitanju materije Konvencije nije bilo, ona je nastala kompromisom dvaju diskursa u kojima su se ocrtali zajednički taktički elementi. Diskurzivna koalicija iskovana u sukobu nadvladala je radikalnije diskurse s lijeva i s desna

${ }^{122}$ Komentar Olivere Škarice uz tekst: "Majka dvoje djece (26) sa Rebra uputila dramatičan apel preko Facebooka", JL, 1. 2. 2019.

123 "Istanbulska konvencija kao odskočna daska za Plenkovića i njegove suradnike sjećate li se kako su je gorljivo zagovarali?", Na, 22. 9. 2019; "Miroslav Škoro: 'Inicirat ću referendum o izbornom zakonu i Istanbulskoj konvenciji'", Na, 20. 10. 2019.

124 Otvoreno, HRT1, 20. 9. 2018. 
u "kulturalnoj" i svjetonazorskoj dimenziji ideoloških podjela. Naracije o vladavini žena i transfobnosti ostale su na margini, kao i tradicionalna zaštita nacionalnog identiteta, dok su radikalni ekonomizam i religijska eshatologija ionako samo mogli konstatirati ono što se događa - ekonomsku mijenu tipičnu za povijest i nastavak raskola tipičan za posljednja vremena. U sjeni prijepora o rodu ostalo je još jedno postroženje kaznene politike, ovoga puta s pozicije partikularnoga aktivističkog diskursa. Kazneni je republikanizam ratifikacijom Konvencije izgubio još jednu bitku. ${ }^{125}$

${ }^{125}$ Članak je dio obuhvatnije analize koja ratifikaciju Istanbulske konvencije smješta u kontekst novijih trendova razvoja kaznene politike u Hrvatskoj, a bit će objavljena kao zasebna studija. 


\section{Literatura}

Butler, Judith. 1990. Gender Trouble: Feminism and the Subversion of Identity. New York: Routledge.

Colebatch, Hal. 2004. Policy. Zagreb: Fakultet političkih znanosti.

Fairclough, Norman. 1992. Discourse and Social Change. Cambridge: Polity.

Foucault, Michel. 1976. Histoire de la sexualité: La volonté de savoir. Pariz: Gallimard.

Geertz, Clifford. 1973. The Interpretation of Cultures. New York: Basic.

Hajer, Maarten. 2003. A frame in the fields: policymaking and the reinvention of politics. U: Hajer, Maarten, Wagenaar, Hendrik. (ur.) Deliberative Policy Analysis: Understanding Governance in the Network Society. Cambridge: Cambridge University Press, str. 88-110.

Hajer, Maarten. 2006. Doing Discourse Analysis: Coalitions, Practices, Meaning. U: Van den Brink, Margo, Metze, Tamara. (ur.). Words Matter in Policy and Planning. Discourse Theory and Method in Social Sciences. Utrecht: KNAG, str. 65-74.
Hrabar, Dubravka. 2018. Istanbulska konvencija i zamke rodne perspektive. Zagreb: Vlastita naklada.

Lasswell, Harold. 1938. Propaganda Technique in the World War. New York: Peter Smith.

Petković, Krešimir. 2018. Ideology and Truth: The Return of the Old Couple in the Post-Truth Era. Političke perspektive. (8) 3: 37-39.

Thompson, John. 1984. Studies in the Theory of Ideology. Berkeley: University of California Press.

Van Dijk, Teun. 2006. Ideologija: multidisciplinarni pristup. Zagreb: Golden marketing - Tehnička knjiga.

Weber, Max. 1988. Gesammelte Aufsätze zur Wissenschaftslehre. Tübingen: J. C. B. Mohr.

Wodak, Ruth, Meyer, Michael. 2016. Critical Discourse Studies: History, Agenda, Theory and Methodology. U: Wodak, Ruth, Meyer, Michael. (ur.). Methods of Critical Discourse Studies. London: Sage, str. 1-22. 


\section{A Discourse Analysis of the Istanbul Convention}

Abstract The author analyzes the case of ratification of the Istanbul Convention in Croatia in 2018. After introductory explanations of the basic theoretical and methodological conditions of the analysis, the first part of the article analyzes the text of the Convention. The second part of the article analyzes its political reception in Croatian public at the time before, during and after its ratification. In doing so, it inductively establishes the discourses that both clashed and collaborated, on the basis of repetitive similarities and differences in the utterances that different actors made in the public media. After the discursive framework of the debate is analyzed, the institutional and non-institutional aspects of the ratification process that took place within these framework are presented. Emphasis is placed on the formation of a discursive coalition between advocates of the dominant discourse on violence against women and the discourse on family tradition that, with the Interpretive statement, enabled the ratification of the Convention.

Keywords Istanbul Convention, Discourse Analysis, Penal Policy, Violence against Women, Domestic Violence, Gender, Power, Ideology 